\title{
Nanoparticles for Stem Cell Tracking and the Potential Treatment of Cardiovascular Diseases
}

\author{
Huihua Huang ${ }^{1,2}$, Xuejun Du' ${ }^{1}$, Zhiguo $\mathrm{He}^{3}$, Zifeng $\mathrm{Yan}^{3}$ and Wei Han ${ }^{1 *}$ \\ 'Emergency Department, Shenzhen University General Hospital, Shenzhen University, Shenzhen, China, ${ }^{2}$ Guangdong Key \\ Laboratory for Biomedical Measurements and UItrasound Imaging, School of Biomedical Engineering, Shenzhen University, \\ Health Science Center, Shenzhen, China, ${ }^{3}$ Advanced Materials Institute, Graduate School at Shenzhen, Tsinghua University, \\ Shenzhen, China
}

\section{OPEN ACCESS}

Edited by:

Shijun Hu,

Soochow University, China

Reviewed by:

Gianandrea Pasquinelli,

University of Bologna, Italy

Donghui Zhang,

Hubei University, China

Lei Ye,

National Heart Centre Singapore,

Singapore

*Correspondence:

Wei Han

sugh_hanwei@szu.edu.cn

Specialty section:

This article was submitted to

Stem Cell Research,

a section of the journal

Frontiers in Cell and Developmental

Biology

Received: 01 February 2021

Accepted: 12 May 2021

Published: 02 July 2021

Citation:

Huang H, Du X, He Z, Yan Z and Han W (2021) Nanoparticles for Stem

Cell Tracking and the Potential

Treatment of Cardiovascular

Diseases.

Front. Cell Dev. Biol. 9:662406. doi: 10.3389/fcell.2021.662406
Stem cell-based therapies have been shown potential in regenerative medicine. In these cells, mesenchymal stem cells (MSCs) have the ability of self-renewal and being differentiated into different types of cells, such as cardiovascular cells. Moreover, MSCs have low immunogenicity and immunomodulatory properties, and can protect the myocardium, which are ideal qualities for cardiovascular repair. Transplanting mesenchymal stem cells has demonstrated improved outcomes for treating cardiovascular diseases in preclinical trials. However, there still are some challenges, such as their low rate of migration to the ischemic myocardium, low tissue retention, and low survival rate after the transplantation. To solve these problems, an ideal method should be developed to precisely and quantitatively monitor the viability of the transplanted cells in vivo for providing the guidance of clinical translation. Cell imaging is an ideal method, but requires a suitable contrast agent to label and track the cells. This article reviews the uses of nanoparticles as contrast agents for tracking MSCs and the challenges of clinical use of MSCs in the potential treatment of cardiovascular diseases.

Keywords: nanoparticles, stem cell therapy, mesenchymal stem cell, cardiovascular diseases, imaging technique

\section{INTRODUCTION}

In the medical world, stem cell-based therapies have emerged and expanded as a potentially promising therapeutic treatment (Heslop et al., 2015). In such a treatment process, stem cells, possessing properties of self-renewal and potency, play a significant role, and under appropriate conditions, these cells can be differentiated into a variety of cells (Srivastava and Ivey, 2006; Maumus et al., 2011; Hao et al., 2014; Aly, 2020). Compared with direct transplantation of tissue or organ for patients, stem cell-based therapies are more promising and potential because these cells can be feasibly and readily obtained avoiding donor shortage and immune incompatibility (Diekman and Guilak, 2013; Lilly et al., 2016). In general, stem cells can be divided into two major types, embryonic stem cells (ESCs) and adult stem cells (ASCs) (Lv et al., 2014). The transplantation of ESCs derived from the early embryo has been demonstrated to be effective in the treatment of many diseases, due to their being highly undifferentiated cells and having the ability of evolving into all tissues and organs (Krebsbach and Robey, 2002; Hao et al., 2009). However, the research for ESCs is controversial, being difficult to accepted by common people (Li et al., 2010). Compared with ESCs, ASCs, which originated from tissues, are easily accepted and have been widely applied 
in preclinical and clinical trials, but leads to low capacity of differentiation (Young and Black, 2004; Ye et al., 2006; Alison and Islam, 2009). For example, the hematopoietic stem cells (bone marrow), originated from ASCs in the blood, can differentiate into various types of mature blood cells, and their transplantation has been used to treat all kinds of blood diseases (Carella et al., 2000; Schmitz et al., 2002; Mikkola and Orkin, 2006; DiPersio et al., 2009; Jaiswal et al., 2009). Neural stem cells, possessing the ability of differentiating into neurons and astroglia, are also derived from ASCs, and their transplantation may treat diseases of the nervous systems (Temple, 2001; Lee et al., 2005, 2009; Andres et al., 2008; Stenudd et al., 2015). In 1970, Friedenstein discovered a rare type of stromal cells in human bone marrow that are now known as mesenchymal stem cells (MSCs) (Friedenstein et al., 1970). Although MSCs have similar abilities to ASCs, there is still a lot of debate about their origin. Moreover, some researchers claimed that the name of MSCs should be changed to medicinal signaling cells in order to accurately reflect the fact that these cells play the role of constructing new tissues (Caplan, 2017). At present, MSCs are found in many tissues beyond the bone marrow, including adipose tissue, lung tissue, synovial membrane, endometrium, and peripheral blood. In different tissues, MSCs exhibit differences in immunophenotype, differentiation potential, and immunomodulatory. The researches show that the transplantation of MSCs is an effectively promising and potentially therapeutic treatment for various diseases including wound healing, ischemic encephalopathy, and ischemic heart disease (Grauss et al., 2007; Wu et al., 2007; Uccelli et al., 2008; Kim et al., 2015a; Xie et al., 2016).

To date, stem cell-based therapies have been intensively employed in the treatment of wounds, blood and cardiovascular diseases, cartilage defect, diabetes, etc. (Goradel et al., 2018; Vagnozzi et al., 2020). However, there are still much to be further explored for stem cell-based therapies, in order to identify therapeutic efficacy and further dosage (Yi et al., 2017). For these purposes, it is necessary to track stem cells in vitro and in vivo with high temporal and spatial resolution in a real-time manner during a prolonged period, which involves monitoring stem cells' behavior in vivo, identifying if they are capable of surviving, integrating with the host tissue, undertaking the desired cellular differentiation, and finally unveiling the responses and behaviors of transplanted cells upon exposure to various diseased environments.

\section{THE MEANS OF TRACKING STEM CELLS AND THE IMPORTANCE OF NANOPARTICLES}

For tracking stem cells, non-invasive cell imaging is currently a very hot field of research (Kircher et al., 2011). Compared with traditional histopathological techniques, non-invasive cell imaging can monitor the behaviors of the transplanted cells over time in vivo for further treatment offering detailed information, thus, showing more efficient therapeutic effects (Cahill et al., 2004; Walczak and Bulte, 2007; Bulte, 2017;
Meir and Popovtzer, 2018; Peng et al., 2018). Only by using noninvasive means can the viability of the transplanted cells be estimated in the clinical setting, showing potential prospects (Shang et al., 2017; Tkaczyk, 2017). Non-invasive cell tracking can be divided into direct and indirect labeling techniques. Compared with direct labeling, which can directly label cells, possessing easy operation but being unable to track daughter cells due to fast signal decay, indirect labeling obtains the ability of labeling cells by implanting an indicator into cells (Li et al., 2008; Kraitchman and Bulte, 2009; Kim et al., 2016a,b). Although indirect labeling is complex and expensive, it is more effective and stable for tracking the differentiation of the transplanted cells (Davis, 1972; Akins and Dubey, 2008; Hong et al., 2010). In general, indirect labeling can be divided into two major classes, gene modification and external label. Gene modification is suitable for long-term tracking because the labeled genes can be steadily expressed in the next generation (Chan et al., 2017; Su et al., 2019). However, the imaging technique of gene modification is single and only being detected by a tracking fluorophore leading to the limitation of tissue penetration (Herschman, 2004; Loewen et al., 2004). In addition, the labeled genes are derived from exosomes, leading to immune incompatibility (Zheng et al., 2017). Another indirect labeling method, external label, can overcome the obstacle of the foreign gene by introducing additional contrast agents, but it still has some limitations (Crabbe et al., 2010; Li et al., 2013; Hachani et al., 2017). Because the introduction of contrast agents brings some new problems, including the reduction effect of photo-signal over time, optical interference is induced by tissue autofluorescence, incompatibility, cytotoxicity, and low labeling efficiency (Bellin, 2006; Cosgrove, 2006; Lusic and Grinstaff, 2013). Thus, an appropriate contrast agent should be developed and utilized to break through these limitations.

Nanoparticles (NPs), the diameter of which ranges from 1 to $100 \mathrm{~nm}$, cover a diverse range of chemical composition with an equally diverse number of applications (Khan et al., 2019). Due to their nanoscale dimensions, NPs can easily transport across cell membrane and reach the crucial organelles including the endoplasmic reticulum, mitochondria, and nucleus (McNamara and Tofail, 2017). Moreover, a high surface area-over-volume ratio augments their interaction with cellular components (Bhirde et al., 2011; Edmundson et al., 2013). Furthermore, the morphology and size of NPs determine their physicochemical properties leading to the differences in cellular uptake and interaction with biological tissues, which could not be achieved by bulk materials (Barua and Mitragotri, 2014). As a result, NPs have been regarded as a promising contrast agent. Nowadays, nanotechnology in medical science has been regarded as a great breakthrough in this century (Zhang et al., 2008; Lin, 2015). Importantly, some special NPs have unique magnetic and/or optical properties, which can offer real-time imaging in vivo for tracking the transplanted stem cells, showing a strong potential in breaking through the obstacle of external label (Rhyner et al., 2006; Hahn et al., 2011). These NPs for tracking stem cells include organic, inorganic, and composite NPs, and the representative examples have magnetic NPs and photoacoustic NPs (Van Den Bos et al., 2003; Ferreira, 2009; Wang et al., 2012b; Gao et al., 2013; Accomasso et al., 2016; Riera et al., 2019). 
The transplanted stem cells labeled by these NPs can be detected by multiple imaging methods, such as magnetic resonance imaging (MRI), nuclear imaging [including singlephoton emission computed tomography imaging (SPECT) and positron emission tomography-computed tomography (PET$\mathrm{CT}$ )], and photoacoustic imaging (Sutton et al., 2008; Andreas et al., 2012; Cheng et al., 2016; Guo et al., 2019b; Patrick et al., 2020). However, there are still many problems to be addressed in the actual application process for NPs. First, NPs for tracking stem cells in vivo always require good cellular uptake and efficient internalization. Therefore, the surface chemistry of NPs should be importantly considered (Accomasso et al., 2016). In most cases, NPs with positive charge have the improvement of cellular uptake due to electrostatic interaction, leading to an accelerated internalization (Saha et al., 2013; Behzadi et al., 2017). Certainly, NPs with positive charge also may delay their internalization process, due to the influence on the adsorption of some specific proteins (Jambhrunkar et al., 2014). Second, importantly, before use, NPs should be comprehensively characterized for their composition and purity under different conditions, in order to evaluate their toxic effects on cells and ensure safety in vivo (Chandran et al., 2017). The reasons are that their toxic effects on cells may highly depend on the unique characteristics of NPs themselves. What is more, compared with bulk material, NPs have higher surface area-to-volume ratio and surface reactivity, which are more susceptible to the environment, so they should be modestly employed (Alkilany and Murphy, 2010; Lankoff et al., 2012). In addition, close attention should be paid to the agglomeration of NPs, which may lead to bad cellular uptake and further induced cytotoxicity (Gliga et al., 2014).

The internalization of NPs is influenced by their charge, size, shape, and the ability of cellular uptake, due to the force of their internalization driven by endocytosis. After internalization by endocytosis, NPs will pass environments of lysosomes and peroxisomes where the acidic material and oxidative substance could entirely degrade them. Possibly, a part of them may undergo exocytosis or escape to other intracellular locations (Chen et al., 2013; Calero et al., 2014).

\section{NANOPARTICLES FOR TRACKING MSCS AND THE POTENTIAL TREATMENT OF CARDIOVASCULAR DISEASES}

Cardiovascular diseases (CVDs), with high incident, are one of the major causes of human deaths worldwide and responsible for more than 17.7 million deaths in 2015, according to the World Health Organization (Zampelas and Magriplis, 2020). Therefore, developing an effective means for treating CVDs is of paramount urgency (Behlke et al., 2020). Currently, the means for treating CVDs include, but are not limited to, surgical treatment, delivering the targeted drug, and the repair and regeneration of the cardiac tissues (Godin et al., 2010; Cui et al., 2016; Deng et al., 2020). However, surgical treatment and targeted drug delivery only can delay and relieve the progression of CVDs but are unable to solve the inherent problems due to the deficiency of the regeneration for dead heart cells. In regenerative medicine, adult stem cell-based therapies have been shown as a promising potential for treating cardiovascular diseases in preclinical trials because the repair and regeneration of the cardiac tissues can be expected to solve the differentiation of stem cells into heart cells, thereby, offering improved efficacy (Kastrup, 2011). In these cells, MSCs play an important role in the therapy of CVDs, due to their ability of self-renewal and differentiating into various types of cells, including cardiovascular cells (Caplan, 2009; Ye et al., 2014). Moreover, after transplantation of MSCs, they can generate a structure resembling cardiac myocytes and exert antiinflammatory effects, which can protect the myocardium, further improving the repair of the cardiovascular system. Notably, MSCs have been demonstrated by preclinical studies to have a strong ability to generate blood vessels with minimal adverse effects on the tissues near the injected region. Therefore, the transplantation of MSCs is potentially promising to improve the treatment of CVDs (Trivedi et al., 2010; Goradel et al., 2018; Guo et al., 2020). Despite its great potential for CVD treatment, MSC-based therapies still face some challenges, for example, the real-time tracking for MSC fate after their transplantation, which can provide information such as cell differentiation, the role that MSCs play in vascular repair, and mechanisms of cardiovascular regeneration to guide therapy process and improve therapeutic effect.

Cell imaging is an ideal method for real-time tracking of MSCs, but requires a suitable contrast agent to label MSCs. NPs are a group of contrast agent, which have been widely applied in MSC tracking (Zhang and Wu, 2007; Fu et al., 2011; Liang et al., 2013; Santoso and Yang, 2016; Yi et al., 2017; Guo et al., 2019a). Especially, MSCs labeled by magnetic and/or optical NPs can directly be imaged to offer a real-time tracking in vivo (Jing et al., 2008; Betzer et al., 2014; Wu et al., 2014; Perez et al., 2017). These NPs include superparamagnetic iron oxide (SPIO) NPs, gadolinium (Gd)-based NPs, gold ( $\mathrm{Au}$ )-based NPs, quantum dots (QDs)-based NPs, upconversion (UC)-based NPs, silicon-based NPs, and several other classes of NPs. Here, we will summarize and discuss in detail NPs for labeling and tracking MSCs in vivo, shown in Table 1.

\section{Superparamagnetic Iron Oxide Nanoparticles}

Generally, SPIO NPs are a kind of NPs with a core-shell structure, in which the core is composed of an iron oxide and then is covered by a coating layer as the shell. The coatings layer alters the surface properties of SPIO NPs, and the iron oxide core provides its magnetic properties (Singh et al., 2010; Mahmoudi et al., 2011). Due to unique magnetic properties, SPIO NPs have the ability to generate a strong inhomogeneous field leading to the contraction of $\mathrm{T} 2$ relaxation time, thereby, generating obvious contrast in T2-weighted MRI, and are generally used as a T2contrast agent (Andreas et al., 2012; Li et al., 2013; Bull et al., 2014; Santoso and Yang, 2016; Jiang et al., 2019). So far, SPIOs are the only commercial NPs, several formulations of which have already been approved by the Food and Drug Administration and have been regulated for clinical applications (Wang et al., 2013). MSCs labeled by SPIO NPs can be tracked by MRI, providing a 
TABLE 1 | Comparison between nanoparticles for tracking mesenchymal stem cells (MSCs).

\begin{tabular}{|c|c|c|c|c|c|c|c|}
\hline Example & $\begin{array}{l}\text { Types of } \\
\text { nanoparticles } \\
\text { (NPs) }\end{array}$ & Preparation & $\begin{array}{l}\text { Imaging } \\
\text { modality }\end{array}$ & $\begin{array}{l}\text { Types of } \\
\text { MSCs }\end{array}$ & Advantages & Disadvantages & Main results \\
\hline $\begin{array}{l}\text { Lu et al., 2007; } \\
\text { Andreas et al., } \\
2012\end{array}$ & $\begin{array}{l}\text { Superparamagnetic } \\
\text { iron oxide (SPIO) } \\
\text { NPs }\end{array}$ & Easy & $\begin{array}{l}\text { T2-weighted } \\
\text { magnetic } \\
\text { resonance } \\
\text { imaging (MRI) }\end{array}$ & Human MSCs & Obvious contrast & $\begin{array}{l}\text { Low cell-labeling } \\
\text { efficiency for } \\
\text { MSCs; necessary } \\
\text { to functionalize } \\
\text { SPIO NPs }\end{array}$ & $\begin{array}{l}\text { No apparent influences } \\
\text { on viability of MSCs }\end{array}$ \\
\hline $\begin{array}{l}\text { Babic et al., 2008; } \\
\text { Kim et al., 2011; } \\
\text { Szpak et al., 2013; } \\
\text { Lewandowska- } \\
\text { Łańcucka et al., } \\
\text { 2014; Park et al., } \\
\text { 2014; Liao et al., } \\
\text { 2016; Rawat et al., } \\
\text { 2019; Gu et al., } \\
\text { 2018; Lee et al., } \\
2020\end{array}$ & SPIO NPS & Complex & $\begin{array}{c}\text { T2-weighted } \\
\text { MRI }\end{array}$ & $\begin{array}{l}\text { Human MSCs; } \\
\text { mouse MSCs }\end{array}$ & $\begin{array}{l}\text { Obvious contrast; } \\
\text { enhancement of cellular } \\
\text { internalization }\end{array}$ & $\begin{array}{l}\text { Induce } \\
\text { precipitation of } \\
\text { NPs; perturb the } \\
\text { cell membrane }\end{array}$ & $\begin{array}{l}\text { No apparent influences } \\
\text { on viability of MSCs }\end{array}$ \\
\hline Zhang et al., 2010 & SPIO NPS & Easy & $\begin{array}{c}\text { Proton }\left({ }^{1} \mathrm{H}\right) \mathrm{MRI} \\
\text { images }\end{array}$ & Human MSCs & $\begin{array}{l}\text { High sensitivity of cell } \\
\text { detection }\end{array}$ & $\begin{array}{l}\text { Difficult to } \\
\text { accurately } \\
\text { quantify cell } \\
\text { population }\end{array}$ & $\begin{array}{l}\text { No apparent influences } \\
\text { on viability of MSCs }\end{array}$ \\
\hline Sehl et al., 2019 & SPIO NPS & Complex & $\begin{array}{c}\text { Proton }\left({ }^{1} \mathrm{H}\right) \mathrm{MRI} \\
\text { images }\end{array}$ & Mouse MSCs & $\begin{array}{l}\text { High sensitivity of cell } \\
\text { detection; quantify the } \\
\text { persistence of } \\
\text { transplanted MSCs }\end{array}$ & & $\begin{array}{l}\text { No apparent influences } \\
\text { on viability of MSCs }\end{array}$ \\
\hline $\begin{array}{l}\text { Sherry et al., 1988; } \\
\text { Ratzinger et al., } \\
2010\end{array}$ & Gd-based NPs & Easy & T1-weighted & Human MSCs & $\begin{array}{l}\text { Distinguish some } \\
\text { similar low signal }\end{array}$ & $\begin{array}{l}\text { Low cellular } \\
\text { uptake for MSCs }\end{array}$ & $\begin{array}{l}\text { No apparent influences } \\
\text { on viability of MSCs }\end{array}$ \\
\hline $\begin{array}{l}\text { Kim et al., 2015b; } \\
\text { Santelli et al., } 2018\end{array}$ & Gd-based NPs & Easy & $\begin{array}{c}\text { T1-weighted } \\
\text { MRI }\end{array}$ & Human MSCs & $\begin{array}{l}\text { Distinguish some } \\
\text { similar low signal; } \\
\text { long-term tracking }\end{array}$ & & $\begin{array}{l}\text { No apparent influences } \\
\text { on viability of MSCs }\end{array}$ \\
\hline Huang et al., 2020 & Au-based NPs & Easy & $\begin{array}{l}\text { Photoacoustic } \\
\text { imaging and CT } \\
\text { imaging }\end{array}$ & Mouse MSCs & $\begin{array}{l}\text { Detected in deep tissue } \\
\text { at a high resolution; } \\
\text { directly labeled; } \\
\text { excellent } \\
\text { biocompatibility }\end{array}$ & & $\begin{array}{l}\text { No apparent influences } \\
\text { on viability of MSCs }\end{array}$ \\
\hline $\begin{array}{l}\text { Chen G. et al., } \\
\text { 2015; Li et al., } 2016\end{array}$ & QD-based NPs & Complex & $\begin{array}{l}\text { Fluorescence } \\
\text { imaging }\end{array}$ & Human MSCs & $\begin{array}{l}\text { Longer lifetime than } \\
\text { traditional fluorescence } \\
\text { dye; photochemical } \\
\text { stability }\end{array}$ & $\begin{array}{l}\text { Unsatisfied } \\
\text { cytotoxicity and } \\
\text { stochastic } \\
\text { blinking; the } \\
\text { contradiction of } \\
\text { sensitivity and } \\
\text { definition }\end{array}$ & $\begin{array}{l}\text { No apparent influences } \\
\text { on viability of MSCs }\end{array}$ \\
\hline $\begin{array}{l}\text { Idris et al., 2009; } \\
\text { Ang et al., 2011; } \\
\text { Zhao et al., 2013; } \\
\text { Chen X. et al., } \\
\text { 2015; Ma et al., } \\
2016\end{array}$ & UC-based NPs & Complex & $\begin{array}{c}\text { UC } \\
\text { luminescence } \\
\text { imaging }\end{array}$ & Human MSCs & $\begin{array}{l}\text { Detected in deeper } \\
\text { tissue; more stable and } \\
\text { higher definition }\end{array}$ & $\begin{array}{l}\text { Poor } \\
\text { biocompatibility; } \\
\text { low uptake for } \\
\text { cellular }\end{array}$ & $\begin{array}{l}\text { No apparent influences } \\
\text { on viability of MSCs }\end{array}$ \\
\hline $\begin{array}{l}\text { Huang et al., 2005; } \\
\text { Chen and Jokerst, } \\
\text { 2020; Yao et al., } \\
2020\end{array}$ & Silicon-based NPs & Complex & $\begin{array}{l}\text { Fluorescence } \\
\text { imaging }\end{array}$ & Human MSCs & $\begin{array}{l}\text { Excellent } \\
\text { biocompatibility and } \\
\text { chemical inertness; } \\
\text { easily modified by } \\
\text { bioconjugation; good } \\
\text { cellular uptake }\end{array}$ & & $\begin{array}{l}\text { No apparent influences } \\
\text { on viability of MSCs }\end{array}$ \\
\hline Chen et al., 2019 & Silicon-based NPs & Complex & $\begin{array}{l}\text { Photoacoustic } \\
\text { imaging }\end{array}$ & Human MSCs & $\begin{array}{l}\text { Good biocompatible } \\
\text { and cells tracking } \\
\text { capacity; long time }\end{array}$ & & $\begin{array}{l}\text { No apparent influences } \\
\text { on viability of MSCs }\end{array}$ \\
\hline Gao et al., 2016 & Other-based NPs & Complex & $\begin{array}{l}\text { Aggregation- } \\
\text { induced } \\
\text { emission } \\
\text { imaging }\end{array}$ & $\begin{array}{l}\text { Mouse bone } \\
\text { marrow-derived } \\
\text { MSCs }\end{array}$ & $\begin{array}{l}\text { Possessing long-term } \\
\text { tracking and strong } \\
\text { anti-photobleaching } \\
\text { ability }\end{array}$ & & $\begin{array}{l}\text { No apparent influences } \\
\text { on viability of MSCs }\end{array}$ \\
\hline Yin et al., 2018 & Other-based NPs & Complex & $\begin{array}{l}\text { Photoacoustic } \\
\text { imaging }\end{array}$ & Human MSCs & $\begin{array}{l}\text { High signal-to-noise; } \\
\text { deeper tissue imaging }\end{array}$ & & $\begin{array}{l}\text { No apparent influences } \\
\text { on viability of MSCs }\end{array}$ \\
\hline
\end{tabular}


non-invasive method to monitor the fate of transplanted MSCs in vivo (Li et al., 2013; Bull et al., 2014; Guldris et al., 2017; Xie et al., 2019; Elkhenany et al., 2020).

However, MSCs lack phagocytic capacity, and the surface charge of SPIO NPs are negative, which is a similar charge to that of the cellular membrane. Therefore, the internalization of SPIO NPs is limited, leading to a low efficiency of cell labeling. In order to solve these problems, it is necessary to functionalize SPIO NPs by introducing positive charges or other cell membranepenetrating moieties on the surface (Lu et al., 2007; Andreas et al., 2012). Moreover, these unique functionalized surfaces also increase the stability of SPIO NPs in hydrophilic conditions, as well as are used as a coating layer for delaying the degradation of the iron oxide core (Barrow et al., 2015). For example, the uses of cationic polymers such as poly-L-lysine (PLL) and chitosan have commonly been utilized to improve the cellular internalization of SPIO NPs and protect them from being easily degraded in vivo (Babic et al., 2008; Szpak et al., 2013; Lewandowska-Łańcucka et al., 2014; Park et al., 2014). As an MRI probe for tracking MSCs, PLL-SPIONs were more efficient and safer than naked iron oxide NPs, which was in accordance with the fact that their $R_{2}$ value was higher than that of uncoated nanoparticles. However, the highly positive charge of PLL induced the precipitation of NPs and perturbed the cell membrane. Liu et al. (2011) used polyethylenimine with a low molecular weight $(2 \mathrm{kDa})$ to wrap SPIO NPs and obtain PEI-SPIO NPs, which could be readily internalized by MSCs for long-term tracking (19 days). Compared with single SPIO NPs, the modified SPIO NPs hold a controlled clustering structure, leading to much higher T2 relaxivity. Moreover, Lewin et al. (2000) used a short HIV-Tat peptide to functionalize SPIO NPs, which could be effectively engulfed by hematopoietic and neural progenitor cells. The results suggested that the cellular uptake of iron can reach an extremely high level (10-30 pg per cell) showing effective cell labeling and MRI tracking. However, NPs functionalized by cationic polymer or molecules may cause a certain level of toxicity, although it would drastically enhance cellular uptake of NPs. Therefore, some researchers (Kim et al., 2011; Liao et al., 2016) utilized 2-aminoethyl-trimethyl ammonium (TMA) to modified SPIO NPs. It was found that TMA-SPIO NPs could easily and efficiently label MSCs to monitor their fate in vivo, and the labeled MSCs showed low cytotoxicity. In another work, Gu et al. (2018) synthesized PA-SPIO NPs using a self-assembled lipopeptide amphiphile (PA) to modify the surfaces of SPIO NPs for labeling mouse MSCs. The modified NPs showed the enhancement of labeling efficiencies and the improvement of their contrast by shortening the relaxation time. In addition, these NPs exhibited excellent dispersibility and stability in water. More importantly, MSCs labeled by the PASPIO NPs were transplanted into mouse, showing no adverse effects on the osteogenic and adipogenic differentiation. Rawat et al. (2019) synthesized SPIO NPs and then used them to label MSCs. The labeled MSCs could be tracked by MRI to understand their fate in vivo. Moreover, these labeled MSCs still maintained differentiation potential. Lee et al. (2020) used poly lactic-co-glycolic acid (PLGA) to modify SPIO NPs, and then utilized fluorescent dye Cy5.5 to functionalize the prepared NPs for labeling and tracking MSCs to investigate the interactions between PLGA-SPIO NPs and MSCs. The results showed that the prepared NPs had no apparent influences on the survival and differentiation of MSCs when the concentration was at $40 \mu \mathrm{g} / \mathrm{ml}$ for more than $96 \mathrm{~h}$, demonstrating that the internalization pathway of MSCs is via endocytosis.

In proton $\left({ }^{1} \mathrm{H}\right)$ MRI images, SPIO NP-labeled cells appear as signal void regions (Miguel et al., 2007). This effect gives rise to enhance the sensitivity of cell detection, but poses challenges for accurate quantification of the cell population as well. Another limitation for SPIO NP-based cell tracking is the lack of specificity in some tissues. It is ambiguous to identify these cells in vivo, as other regions in anatomic MRI appear as dark as well (Zhang et al., 2010). To overcome these limitations, Sehl et al. (2019) utilized the combination of ironbased MRI, ${ }^{19} \mathrm{~F}$ MRI, and MPI cellular imaging technologies to monitor and quantify the persistence of the transplanted MSCs and infiltrate macrophages in vivo, shown in Figure 1. First, MSCs were labeled with iron oxide NPs (ferumoxytol) and then implanted into the hind limb muscle of 10 C578/6 mice. Finally, a perfluorocarbon agent was administered intravenously for uptake by phagocytic macrophages in situ. The ferumoxytol-labeled MSCs were detected by proton $\left(\mathrm{H}^{1}\right) \mathrm{MRI}$ and magnetic particle imaging (MPI). Perfluorocarbon-labeled macrophages were detected by fluorine-19 (19F) MRI. These three modalities are complementary and provide integrated information (specificity, sensitivity, and quantification of cell number). They proposed that these cellular imaging techniques could be used to monitor MSC engraftment over time and detect the infiltration of macrophages at transplant sites.

\section{Gadolinium-Based Nanoparticles}

T1-weighted sequences are often collected before and after infusion of T1-shortening MR contrast agents, so as to reduce the $\mathrm{T} 1$ relaxation times of ${ }^{1} \mathrm{H}$ atoms in water molecules and produce hyperintensities in T1-weighted images appearing white (Na and Hyeon, 2009). Currently, Gd-based NPs are the most widely used T1-contrast agent for labeling and tracking stem cells (Ni and Chen, 2015). Compared with T2-contrast agent of SPIO NPs, T1-contrast agent of Gd-based NPs can distinguish some similar low signal resulting from intrinsic signal in tissue or hemorrhage, due to their capability of generating a bright positive signal. Therefore, a T1-contrast agent generally is predominately employed as a probe in detecting the transplanted stem cells in a low-signal region ( $\mathrm{Na}$ and Hyeon, 2009; Zhu et al., 2013; Robert et al., 2015).

Gd-based NPs usually are complex NPs, being composed of $\mathrm{Gd}^{3+}$ and their chelating ligand of which diethylenetriamine pentaacetic acid (DTPA) is the most common (Sherry et al., 1988; Ratzinger et al., 2010). Modified by DTPA, GD-based NPs reduced cytotoxicity due to the enhancement of hydrophilicity, but also weakened the interaction with the cell membrane leading to low cellular uptake for MSCs. Furthermore, their labeling efficiency was low resulting from the poor targeting ability of MSCs. Considering these problems, Tseng et al. (2010) prepared Gd-based NPs used as an MRI contrast agent to label and track human MSCs. Due to the modification of hexanedione, the 
A
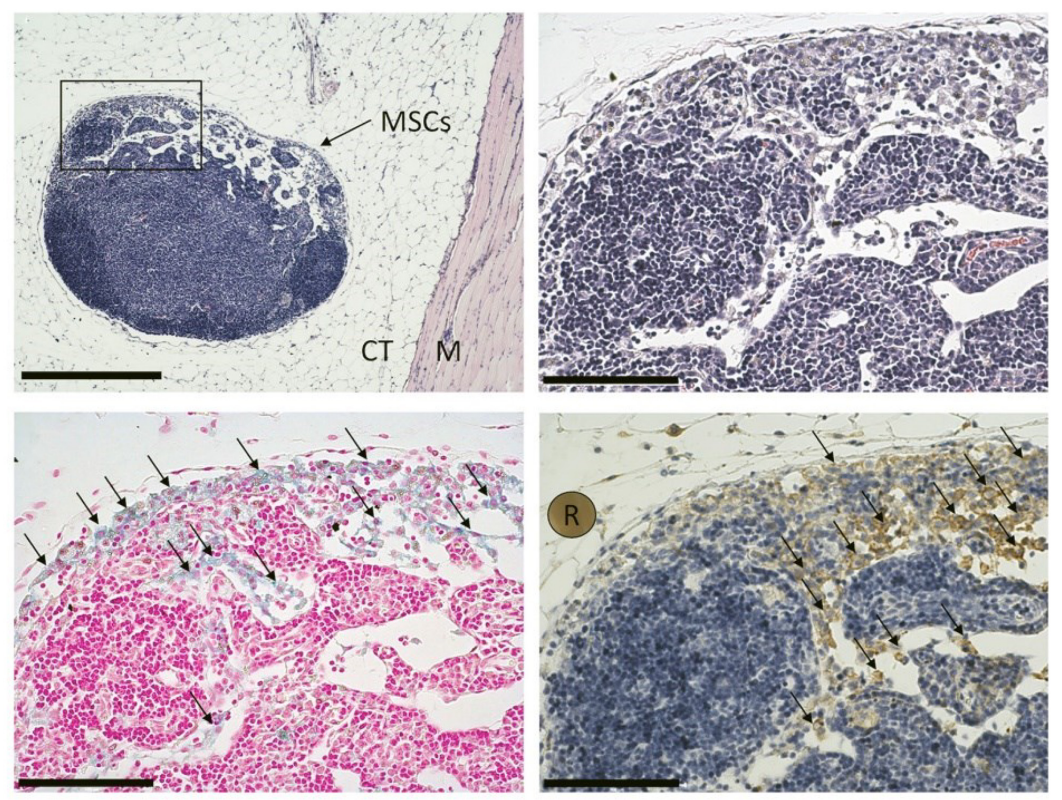

B

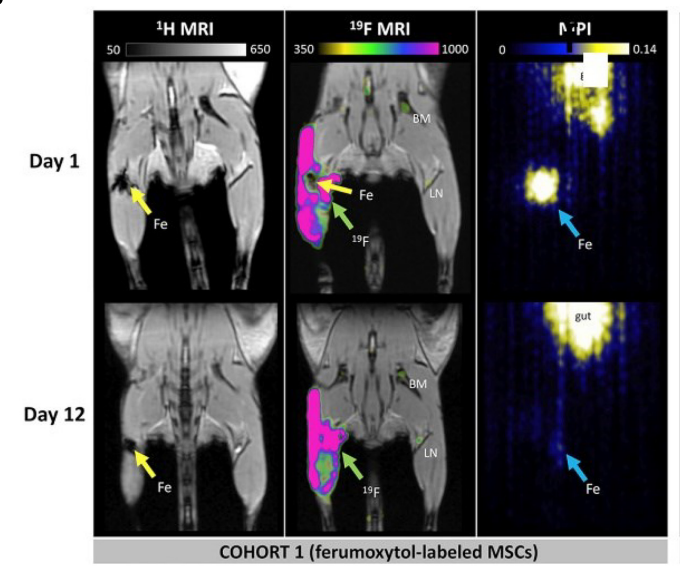

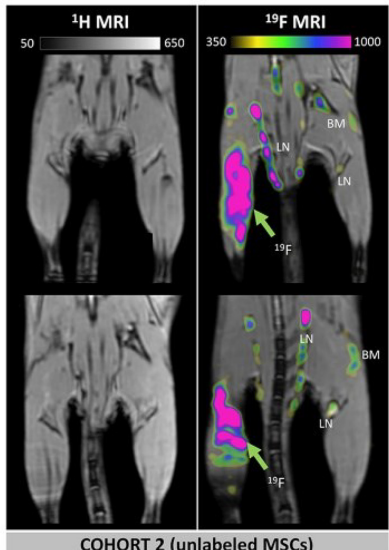

COHORT 2 (unlabeled MSCs)

FIGURE 1 | (A) Histological validation showing the presence of MSCs surrounded in connective tissue (CT) and muscle (M) in hematoxylin and eosin at $\times 10$ magnification (scale bar $500 \mu \mathrm{m})$. (B) In vivo proton $\left({ }^{1} \mathrm{H}\right) /$ fluorine $19\left({ }^{19} \mathrm{~F}\right)$ magnetic resonance imaging (MRI) and magnetic particle imaging (MPI) (adapted Sehl et al., 2019).

biocompatibility of the prepared Gd-based NPs was improved. Moreover, compared with Gd-based NPs modified by DPTA, the prepared Gd-based NPs showed more excellent cellular uptake for MSCs and could be easily detected in vivo due to the shortening of $\mathrm{T} 1$ relaxation times. In another work, Kim et al. (2015b) reported a Gd-based NP to label MSCs, in which $\mathrm{Gd}^{3+}$ was chelated with a pullulan derivative ligand. It was found that the prepared Gd-based NPs could dramatically enhance cellular uptake for MSCs, leading to the enhancement of internalization efficiency from $32 \pm 2$ to $98 \pm 4 \mathrm{pg} \mathrm{Gd} /$ cell. Moreover, the labeled MSCs achieved a long-term tracking of 21 days in vivo, due low signal attenuation. Cai et al. (2017) fabricated Gdbased NPs of $7 \mathrm{~nm}$ for tracking MSCs by utilizing melanin to modify $\mathrm{Gd}^{3+}$. The results showed that Gd-based NPs modified by melanin increased the stability of MRI contrast agent and shorten T1 relaxation time, compared with traditional Gd-based NPs modified by DTPA. The labeled MSCs achieved longterm tracking for more than 4 weeks, due to the enhancement of labeling efficiency. Importantly, the labeled MSCs had no apparent cytotoxicity at a proper concentration of $800 \mu \mathrm{g} / \mathrm{ml}$. However, preclinical studies suggested that for tracking MSCs in vitro and in vivo, the single-imaging technique was difficult to complete, and the integration of multiple labeling means often was required. Consequently, Santelli et al. (2018) developed multimodality imaging to track MSCs labeled by Gd-based NPs, shown in Figure 2. The GD-based NPs composed of spherical europium-doped gadolinium oxysulfide $\left(\mathrm{Gd}_{2} \mathrm{O}_{2} \mathrm{~S}: \mathrm{Eu}^{3+}\right)$ could be detected by MRI, X-ray imaging, and photoluminescence imaging. In the in vitro test, the number of MSCs labeled by $\mathrm{Gd}_{2} \mathrm{O}_{2} \mathrm{~S}: \mathrm{Eu}^{3+}$ was up to 2,500, showing feasible cell tracking. 
A
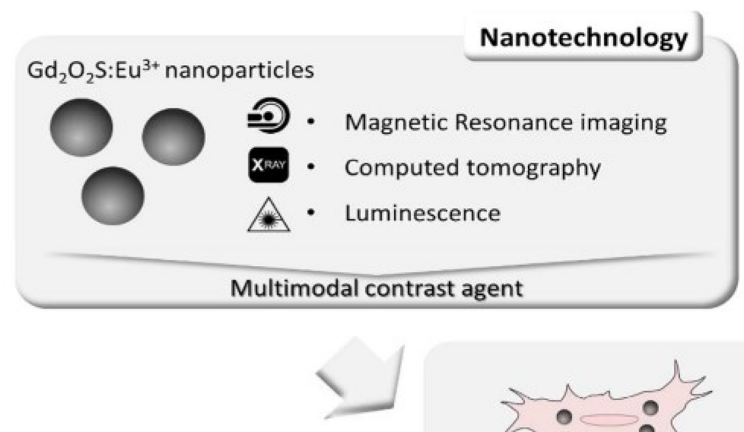

B

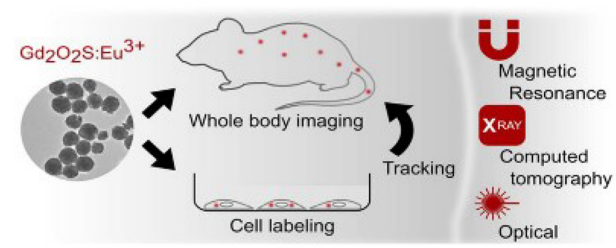

E
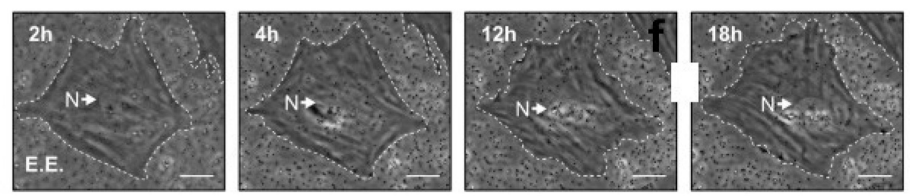

$\mathbf{F}$

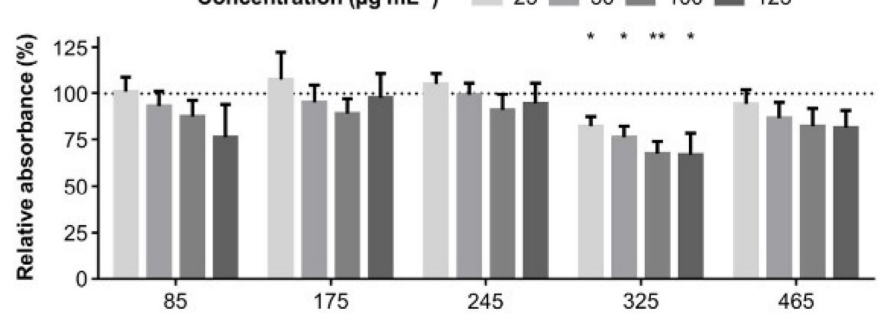

c

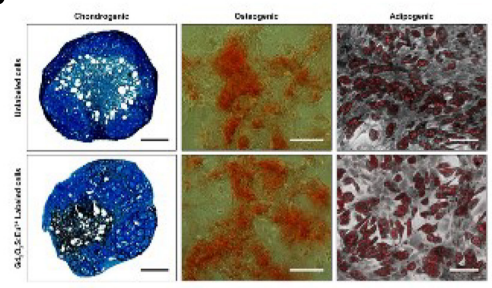

D
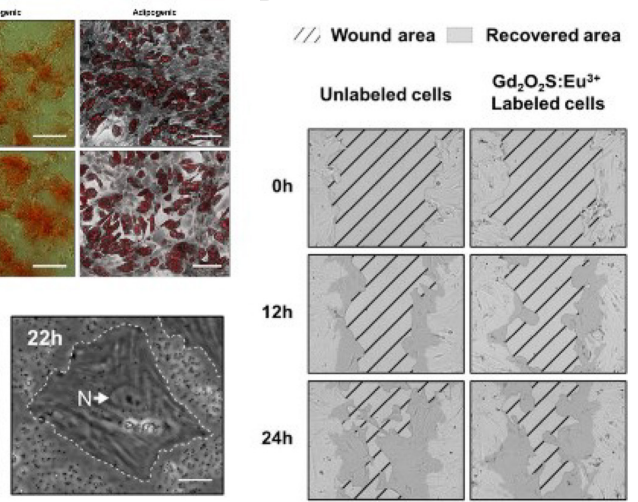

G

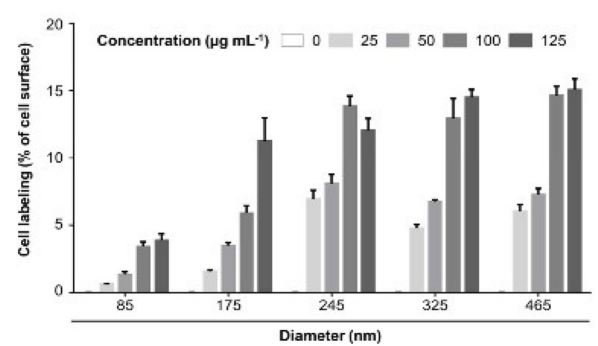

FIGURE 2 | (A) Schematic representation of nanoparticle potential in cell therapy and future impact. (B) Multimodality imaging for tracking mesenchymal stem cells (MSCs). (C) Differentiation of MSCs (scale bar $150 \mu \mathrm{m}$ ). (D) Representative phase-contrast images of wound closing. (E) Time-lapse of labeling extracted from video microscopy acquisition. (F) Viability of MSCs after 24-h $\mathrm{Gd}_{2} \mathrm{O}_{2} \mathrm{~S}: \mathrm{Eu}^{3+}$ labeling evaluated by MTT. (G) Quantification of MSC labeling with $\mathrm{Gd}_{2} \mathrm{O}_{2} \mathrm{~S}$ :Eü ${ }^{3+}$ expressed as the percentage of cell surface area occupied by NPs (adapted by Santelli et al., 2018).

Moreover, the results suggested that the effects of the NPs on viability, proliferation, migration, and differentiation of the transplanted MSCs were innocuousness.

\section{Gold-Based Nanoparticles}

Due to their cytocompatibility and strong optical absorption in the near-infrared region, Au-based NPs are potential contrast agents of photoacoustic imaging. In addition, Au-based NPs can be detected in deep tissue at $2 \mathrm{~cm}$ at a high resolution of $100 \mu \mathrm{m}$, so they are emerging as an alternative method for tracking cells in vivo (Murphy et al., 2008; Giljohann et al., 2010).
More importantly, MSCs can be directly labeled by Au-based NPs, so their differentiation after transplantation in vivo can be detected using photoacoustic imaging in vivo (Turjeman et al., 2015). Donnelly et al. (2018) utilized Au-based NPs as a photoacoustic contrast agent for real-time tracking MSCs to guide their delivery. It was found that the labeled MSCs could be detected by ultrasound/photoacoustic imaging in the spinal cord. In another work, Dhada et al. (2019) prepared Au-based NPs to label and track MSCs by photoacoustic imaging, which was composed of gold nanorods and IR775. The results suggested that cell death also could be detected because IR775 was sensitive 
A
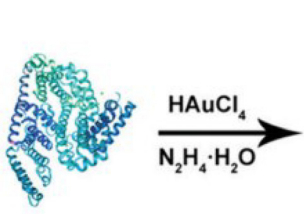

BSA

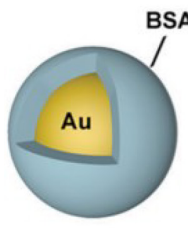

Au@Albumin
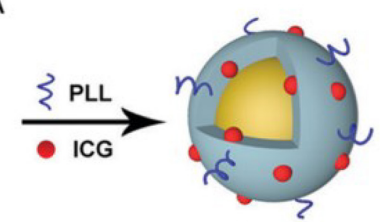

AA@ICG@PLL
B

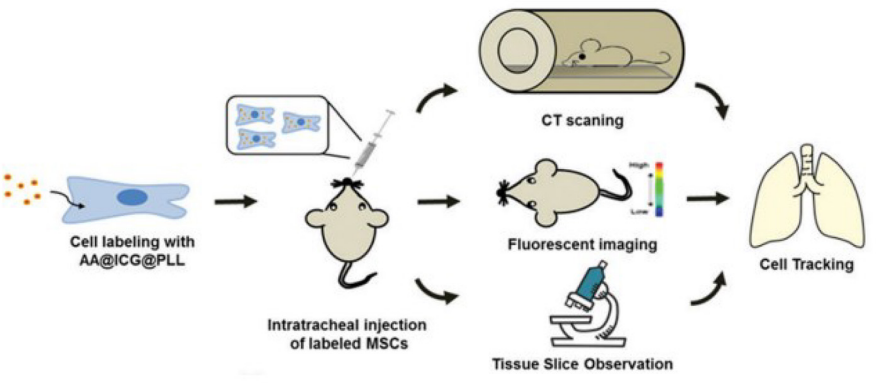

c

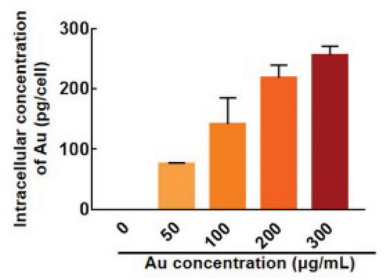

D

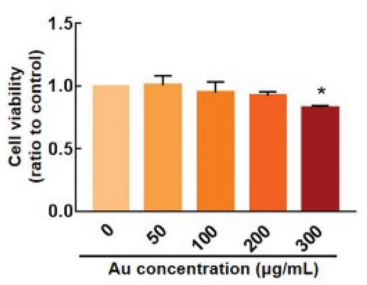

E

Before

After transplantation of labeled BMSC

D 7

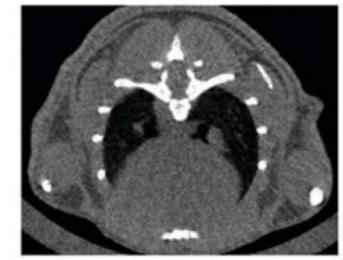

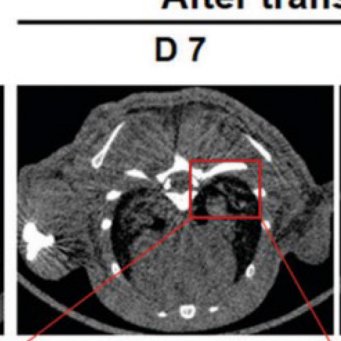
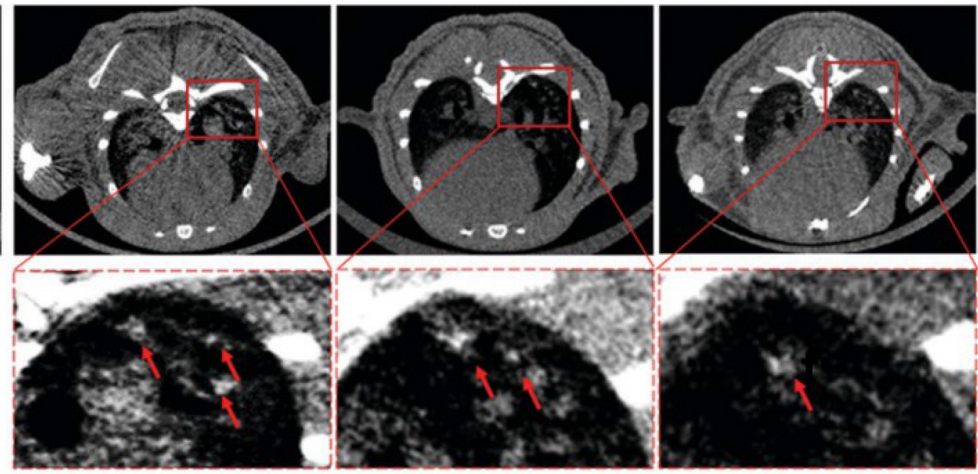

$\mathbf{F}$

Unlabeled

Labeled

Adipogenesis
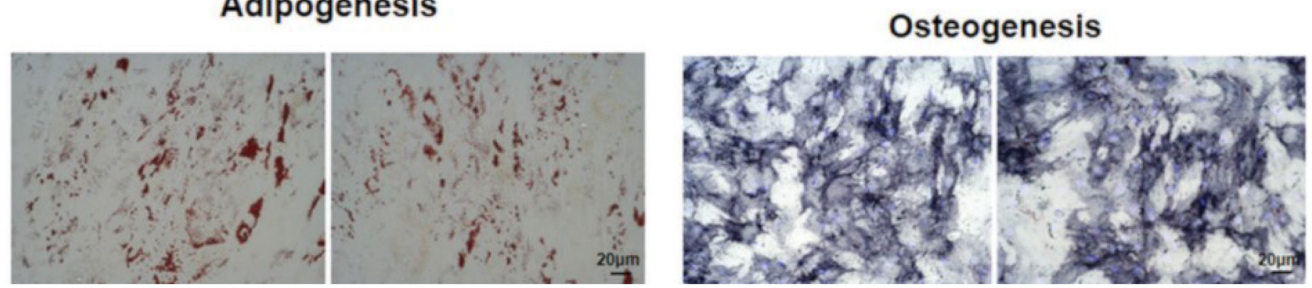

FIGURE 3 | (A) Schematic illustration of the synthesis of AA@ICG@PLL gold (Au)-based nanoparticles (NPS). (B) Experimental design for tracking AA@ICG@PLL-labeled MSCs in a silica-induced PF mouse model. (C) Intracellular Au content measured by ICP-MS. (D) Relative viability of BMSCs labeled with AA@ICG@PLL NPs at various Au concentrations. (E) In vivo computed tomography (CT) images of AA@ICG@PLL-labeled BMSCs at 7, 14, and 21 days after transplantation. (F) Bright-field images of Oil Red O staining and ALP staining of NP-loaded and unloaded BMSCs. Scale bar = 20 mm (adapted by Huang et al., 2020). ${ }^{*} p<0.05$ compared with the unlabeled group.

to reactive oxygen species (ROS). Therefore, the viability of the transplanted MSCs in vivo was quantificationally measured. Moreover, Laffey et al. (2020) studied the viability of MSCs labeled by Au-based NPs in a frozen environment. The results showed that the labeled MSCs undergoing the process of freeing, storing, and thawing for 2 months still could be detected by photoacoustic imaging, and their differential ability also had no apparent difference with the unlabeled MSCs.

Certainly, Au-based NPs also can be detected by computed tomography (CT), due to the high X-ray absorption. Thus, they are used as a CT maker to label and track MSCs. For example, Betzer et al. (2017) used Au-based NPs as labeling agents to 
A
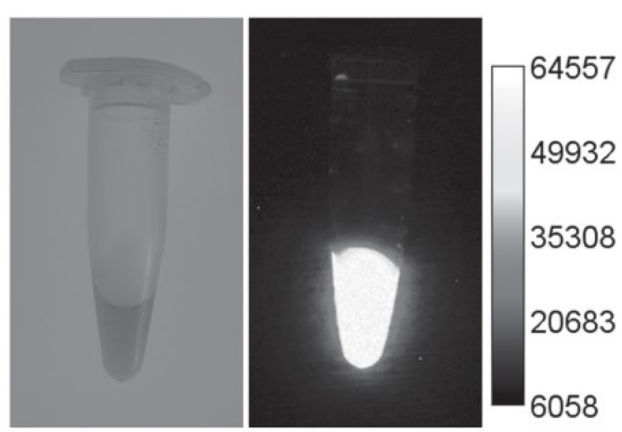

C

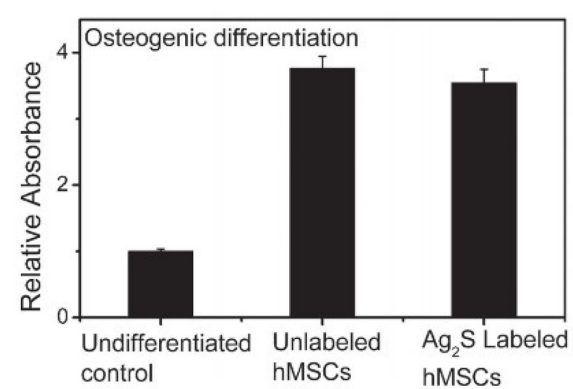

E

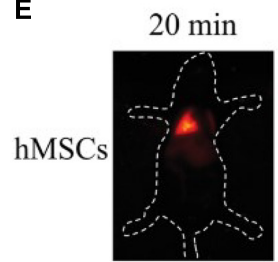

$2 \mathrm{~h}$

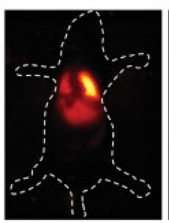

$6 \mathrm{~h}$

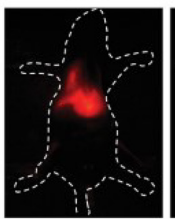

$24 \mathrm{~h}$

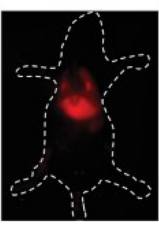

B

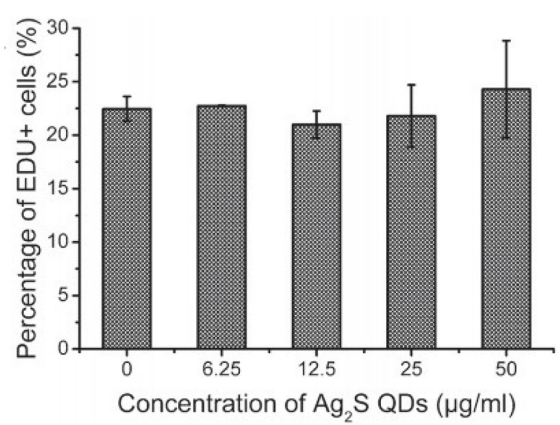

D

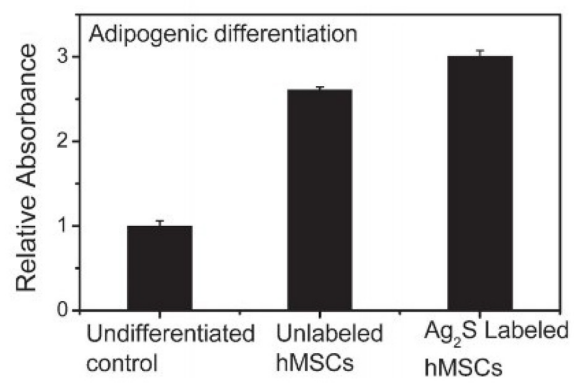

7 day

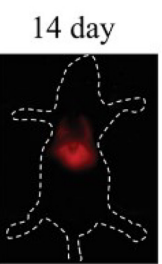

F
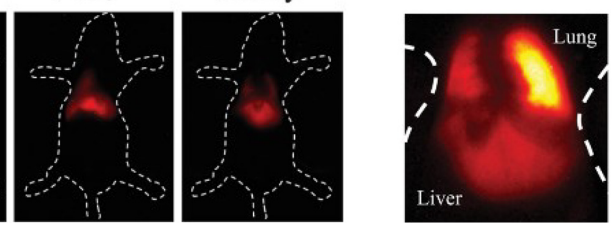

FIGURE 4 | (A) A photoluminescence image (PA) of the $\mathrm{Ag}_{2} \mathrm{~S}$ QD-labeled human MSC solution at a density of $4 \times 10^{6}$ cell $\mathrm{ml}^{-1}$. (B) Cell proliferation. Quantification of (C) osteogenic and (D) adipogenic differentiation by measuring the absorbance of Oil-Red $\mathrm{O}$ and alizarin red extracted from cell lysates at $404 \mathrm{~nm}$, respectively. (E) The time course of the in vivo near-infrared (NIR) PL images of a healthy mouse after transplantation of $\mathrm{Ag}_{2} \mathrm{~S}$ QD-labeled human MSCs. (F) Higher magnification NIR PL image of mice transplanted with human MSCs only after $2 \mathrm{~h}$ (adapted from Chen G. et al., 2015).

longitudinally and quantitatively track MSCs in vivo. It was found that the labeled MSCs were detected for up to $24 \mathrm{~h}$ by CT, showing a long-term tracking. Nafiujjaman and Kim (2020) reported a biocompatible Au-based NPs used as a CT maker, in which Au NPs were modified by poly-L-lysine (PLL) to change the charge properties of surface enhancing the cellular uptake. The MSCs labeled by Au-based NPs could be detected by CT and showed high labeling efficiency. Huang et al. (2020) synthesized Au-based NPs (AA@ICG@PLL) with dual-modal imaging (CT and nearinfrared fluorescence) to label and track MSCs of mice in vivo, shown in Figure 3. Due to modification by indocyanine green (ICG) and poly-L-lysine (PLL), AA@ICG@PLL showed excellent cellular uptake for MSCs and biocompatibility. It was found that the labeled MSCs could be tracked via dual-modal imaging for more than 21 days, and importantly, the prepared NPs had anti-inflammatory properties.

\section{Quantum Dot-Based Nanoparticles}

QD-based NPs are semiconductor NPs with II-VI or III-V elements, which can emit particular frequency light after being stimulated (Jaiswal et al., 2004). The emitted light frequency depends on the size and shape of QD-based NPs. Therefore, QD-based NPs show different colors (Seleverstov et al., 2006). In general, the fluorescence lifetime of QD-based NPs is longer than traditional fluorescence dye (Bailey et al., 2004). In addition, compared with fluorescent dye, QD-based NPs are easier to be detected due to the non-overlapping of absorption and emission (Mazumder et al., 2009). Specifically, QD-based NPs have broad absorption of continuous distribution, but show narrow and symmetrical properties (Yukawa and Baba, 2017). More importantly, they have the advantage of photochemical stability. As a result, QD-based NPs have been used as contrast agents for long-term tracking of MSCs in vivo. However, QDbased NPs also have some disadvantages, such as unsatisfied cytotoxicity and stochastic blinking. Moreover, the augmentation of QD-based NPs in dosage increases the sensitivity of cell imaging, but may decrease their definition (Shah et al., 2007; Liang et al., 2013).

Hsieh et al. (2006) reported a QD-based NP to label human MSCs, in which CdSe was used as the core, and the shell was covered by $\mathrm{ZnS}$. In addition, the commercial QD-based NPs also were developed and utilized as contrast 
A

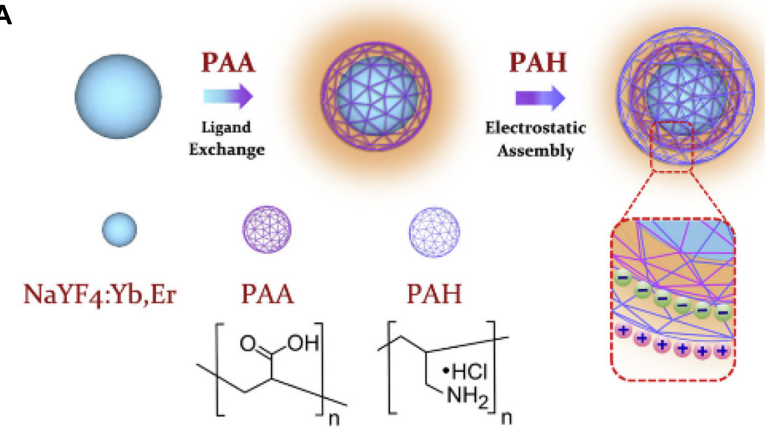

C

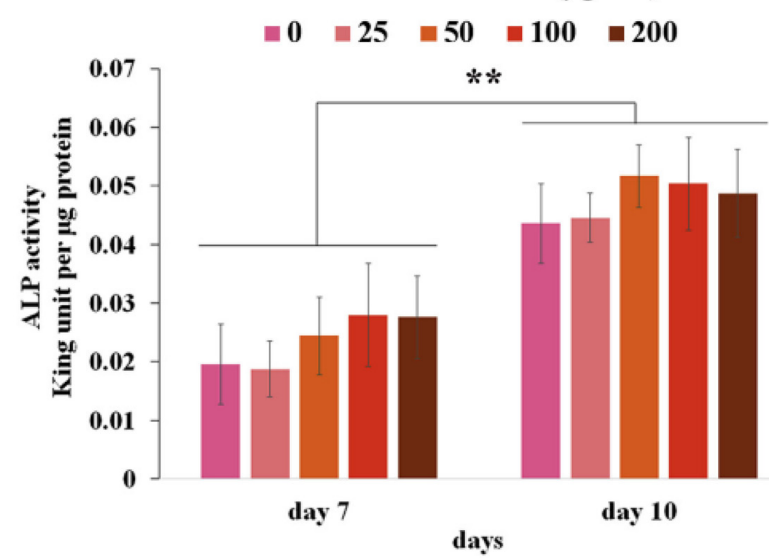

B

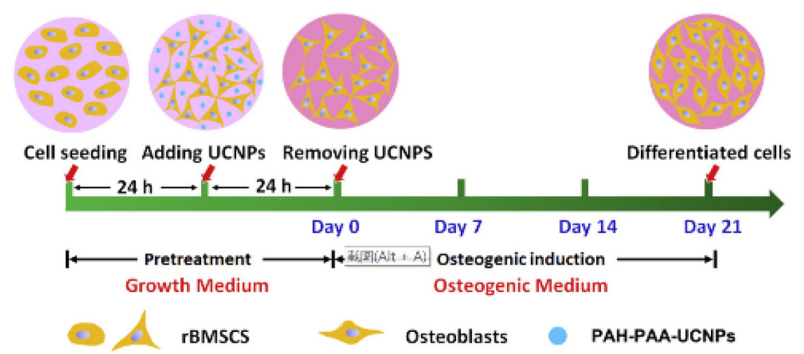

D

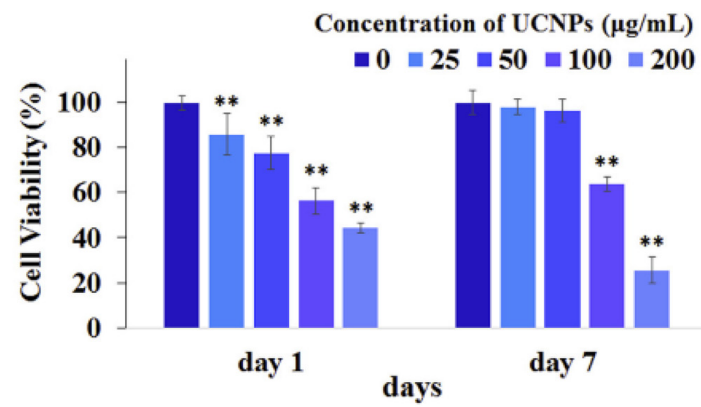

FIGURE 5 | (A) Upconversion (UC)-based NPs synthesis. (B) Cell pretreatment and osteogenic differentiation process. (C) Normalized alkaline phosphatase activity expression by MSCs. (D) Cell viability (adapted by Ma et al., 2016). ${ }^{* *} p<0.01$ compared with control group.

agents to label and track the cell distributions. However, these QD-based NPs showed unsatisfied biocompatibility and cytotoxicity, so they had to be modified before use. In recent years, Li et al. (2016) prepared QDs-based NPs (RGD- $\beta$-CDQDs) to label and track human MSCs, which were composed of QDs, $\beta$-cyclodextrin ( $\beta$-CD), and Cys-Lys-Lys-ArgGly-Asp (CKKRGD) peptide. The QDs modified by $\beta$-CD enhanced the cellular uptake and facilitated the differentiation of MSCs, due to the small molecule dexamethasone and siRNA carried by $\beta$-CD. More importantly, the labeled MSCs could be detected for up to 3 weeks. Chen G. et al. (2015) reported a $\mathrm{AgS}_{2}$ QD-based NP for tracking human MSCs in vivo by utilizing fluorescence imaging, shown in Figure 4. It was found that the prepared NPs with good biocompatibility could be detected in the second near infrared, and the stability of fluorescence reached up to 30 days. Furthermore, the labeled MSCs was dynamically visualized at high resolution of $100 \mathrm{~ms}$ for more than 14 days. Chetty et al. (2019) prepared $\mathrm{CuInS}_{2}-\mathrm{ZnS}$ QD-based NPs to label umbilical cord-derived MSCs, and the labeling efficiency reached 98\% due to the prepared QD-based NPs displaying high photoluminescence quantum yield of $88 \%$. In addition, the labeled MSCs showed no apparent influences on stemness and had the ability of long-term tracking.

\section{Upconversion-Based Nanoparticles}

UC-based NPs, usually being lanthanide-doped nanocrystals, can undergo a photon UC process in which the sequential absorption of two or more photons leads to anti-Stokes type emission of a single higher-energy photon (Wang et al., 2010). Due to the unique properties of being sensitive to the near-infrared light, UC-based NPs can be detected in deeper tissue compared with traditional contrast agents with fluorescence. More importantly, the imaging of UC-based NPs is more stable and has higher definition (Ang et al., 2011; Chen X. et al., 2015).

Idris et al. (2009) reported a contrast agent of UC-based NPs to label and track MSCs, which was composed of $\mathrm{NaYF}_{4}: \mathrm{Yb}, \mathrm{Er}$ NPs, and silicon. The labeled MSCs could directly be imaged in vivo to dynamically visualize their behaviors, but the region imaged by confocal microscopy was small. Wang et al. (2012a) fabricated UC-based NPs to label MSCs, which was modified by polyethylene glycol (PEG) and oligo-arginine. MSCs labeled by the UC-based NPs were detected by fluorescence imaging in vivo, and the introduction of oligo-arginine improved the cellular uptake of the NPs, showing excellent labeling efficiency and high sensitivity of 10 cells. In another work, Cheng et al. (2013) developed a multifunctional UC-based NP, integrating magnetic properties into UC luminescence NPs. Utilizing the 
A

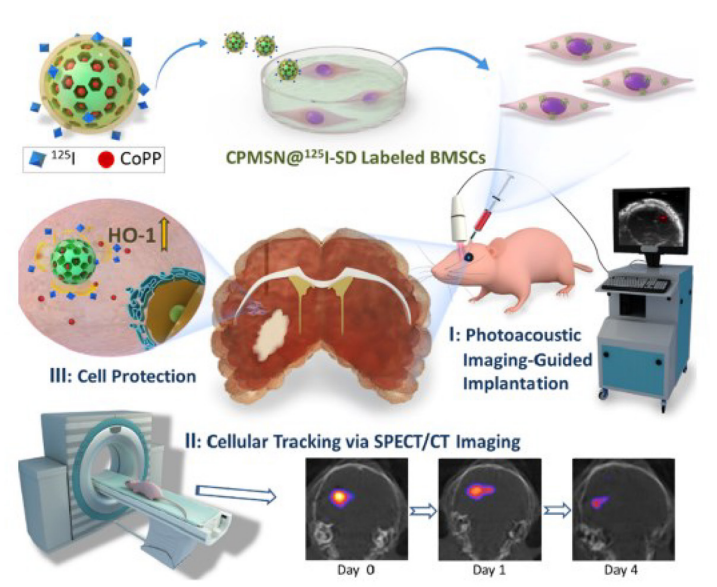

A

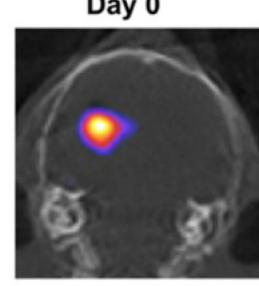

D

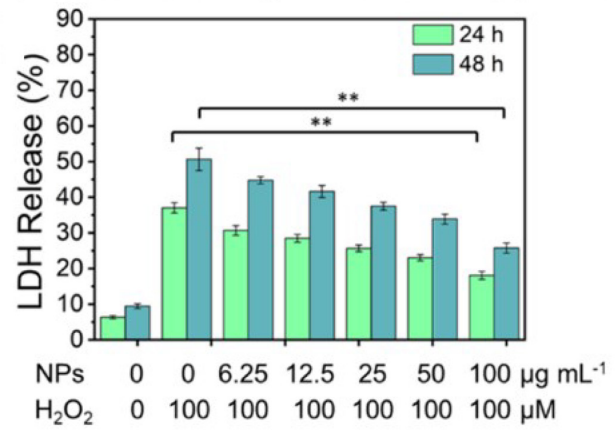

Day 3

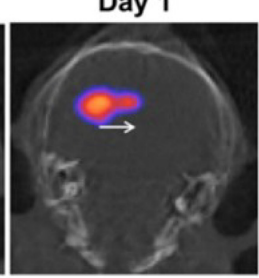

B
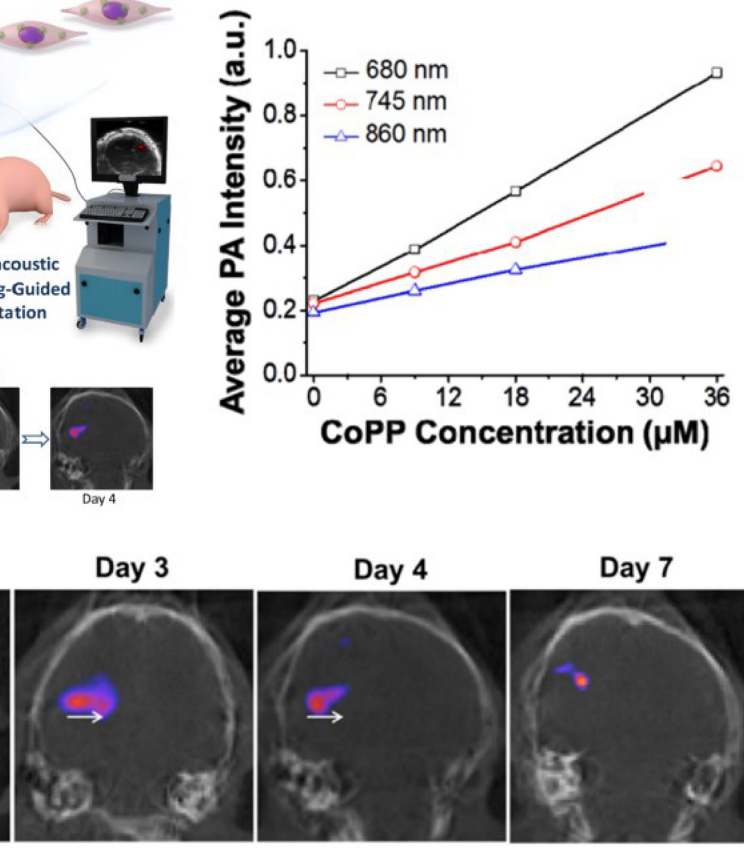

Day 7

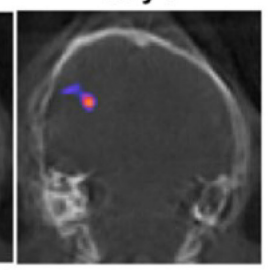

E

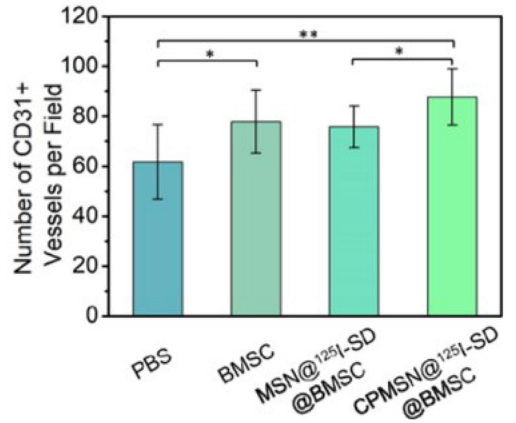

FIGURE 6 | (A) Schematic illustrating the triple functionality of CPMSN@125I-SD for stem cell therapy of brain ischemia. (B) Corresponding average intensities of CPMSN@125I-SD with various cobalt protoporphyrin IX (CoPP) concentrations in the NIR region. (C) Single-photon emission computed tomography imaging (SPECT)/CT images of ischemic mouse brain tissue on different days (0-7 days) after intracerebral injection of the labeled BMSCs (500,000 cells). (D) Cell death assessment for MSCs after treatment with different concentrations of CPMSN@125I-SD (0-100 $\mu \mathrm{g} \mathrm{ml}^{-1}$ ) and exposure to $100 \mu \mathrm{M} \mathrm{H}_{2} \mathrm{O}_{2}$ for 24 and $48 \mathrm{~h}$. (E) Bar graph showing the quantification of the number of $\mathrm{CD}^{31+}$ cells (adapted from Yao et al., 2020). ${ }^{*} p<0.05 ; * * p<0.01$.

prepared NPs, the labeled MSCs can be tracked via fluorescence imaging and MRI, possessing highly effective sensitivity of 10 cells in mouse in vivo. Zhao et al. (2013) prepared a UCbased NP for labeling mouse MSCs, which was composed of polyethylenimine (PEI) and $\left(\alpha-\mathrm{NaYbF}_{4}: \mathrm{Tm}^{3+}\right) / \mathrm{CaF}_{2}$, enhancing the detective depth in vivo due to absorption and emission for near-infrared light.

In recent years, Ma et al. (2016) reported a UC-based NP, which was composed of $\mathrm{NaYF}_{4}: \mathrm{Yb}^{3+}, \mathrm{Er}^{3+} \mathrm{NPs}$, poly (acrylic acid) (PAA), and poly (allylamine hydrochloride) (PAH), as a fluorescence maker for tracking bone marrow MSCs in vitro, shown in Figure 5. The biocompatibility and cellular uptake of $\mathrm{NaYF}_{4}: \mathrm{Yb}^{3+}, \mathrm{Er}^{3+} \mathrm{NPs}$ were highly enhanced, due to electrostatic interaction. Moreover, it was found that the effects of cellular uptake of UC-based NPs $(\leq 50 \mu \mathrm{g} / \mathrm{ml})$ on the osteogenic differentiation had no apparent difference by tracking the MSCs. Kang et al. (2018) prepared a UC-based NP with NIR-controllable properties to label MSCs. By a remote-controllable way, the stem cell differentiation was regulated. Furthermore, Ren et al. (2020) used ligand-free NaYF4:Yb/Er UC-based NPs to label and track mouse bone MSCs, demonstrating that the UC-based NPs at a proper concentration could enhance osteogenic differentiation.

\section{Silicon-Based Nanoparticles}

Recently, silicon-based NPs have been demonstrated as a good contrast agent to label cells because they can be easily modified by bioconjugation (Shin et al., 2019). Furthermore, it has excellent biocompatibility and chemical inertness, thus, being able to serve as a probe for tracking cells in vivo (Huang et al., 2005; Hsiao et al., 2008). Silicon-based NPs, being simply divided into 

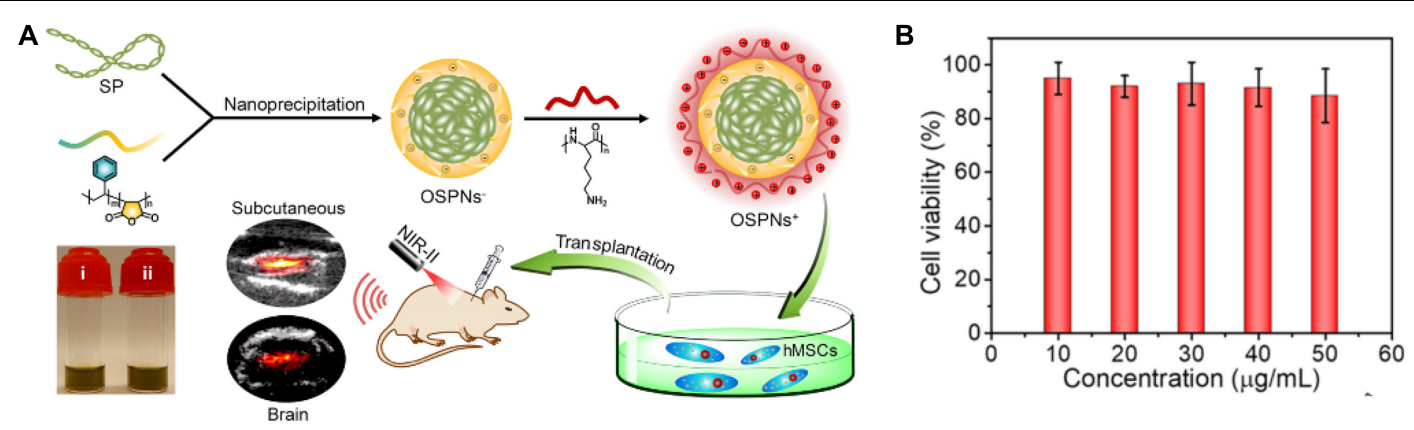

c

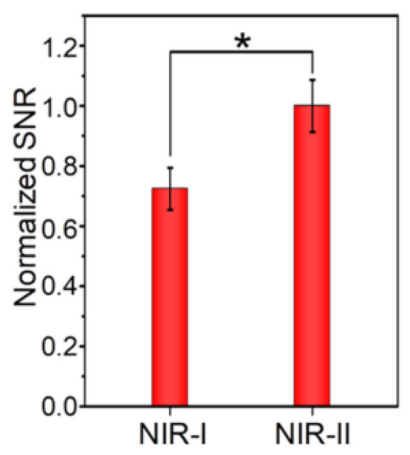

D

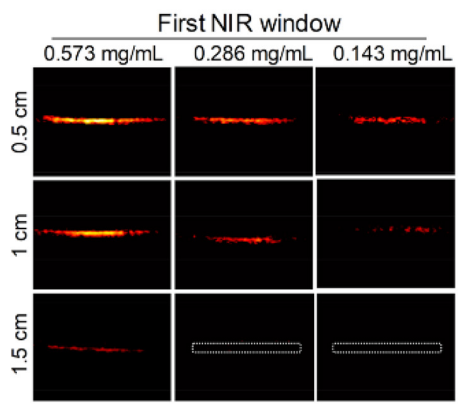

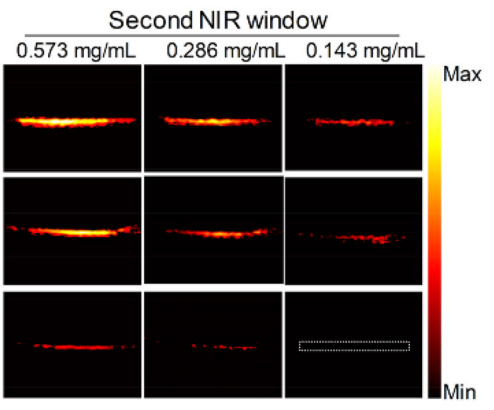

FIGURE 7 | (A) Illustration of the preparation procedure of OSPNs ${ }^{+}$and the photoacoustic labeling of human MSCs after transplantation. (B) The MTT assay of human MSCs treated by OSPNs ${ }^{+}$for 12 h under various concentrations. (C) Normalized PA SNR of OSPNs ${ }^{+}$-labeled hMSCs implanted into mice brain under NIR-I $(860 \mathrm{~nm})$ or NIR-II $(1,064 \mathrm{~nm})$ light excitation ( $\left.{ }^{\star} p<0.05\right)$. (D) PA imaging of aqueous OSPNs ${ }^{+}$solutions $(0.573,0.286$, and $0.143 \mathrm{mg} / \mathrm{ml})($ adapted from Yin et al., 2018).

silica NPs and silicon carbide NPs, not only contain fluorescent properties but also are used as ultrasound agents (Chen and Jokerst, 2020; Yao et al., 2020).

Huang et al. (2005) prepared a mesoporous silica NP modified by fluorescein isothiocyanate, and the labeled MSCs could be detected by imaging to track their viability in vivo. Due to clathrin-mediated endocytosis, the NPs could be internalized into MSCs and showed good cellular uptake. In addition, the highly efficient labeling had no apparent influences on the viability of MSCs. In another work, Chen and Jokerst (2020) used silica NPs to label MSCs and then track the MSCs in vivo by ultrasound imaging. The results showed that silica NPs could significantly increase the ultrasound signal of MSCs in vivo. Yao et al. (2020) reported a unique core-shell NP in which the core is composed of cobalt protoporphyrin IX (CoPP)-loaded mesoporous silica NPs, and the shell is a ${ }^{125} \mathrm{I}$-conjugated/spermine-modified dextran polymer, to label and guide the transplantation of MSCs by PA imaging and SPCT nuclear imaging, shown in Figure 6. The obtained NPs not only could instantly image the transplantation of MSCs but also quantitatively tracked their migrations for a long time. Significantly, the NPs steadily released CoPP to increase the survival of MSCs in ischemic mice.

Another type of silicon-based NPs is silicon carbide NPs, which are commonly used as protecting layer due to their unique properties of being durable and chemically inert. Moreover, typically, silicon carbide NPs $(\leq 10 \mathrm{~nm})$ are utilized as contrast agents to label and track cells in vivo because of their photoluminescence resulting from quantum confinement effects. Chen et al. (2019) used three sizes of silicon carbide NPs to label MSCs, showing dual modality imaging (photoluminescence and photoacoustic imaging). When the size of the NPs is $620 \mathrm{~nm}$, the labeled MSCs could be detected in vitro for more than 20 days. Moreover, the NPs also exhibited good biocompatibility and the capacity of cell tracking because the differentiated cells also could be imaged.

\section{Other Nanoparticles}

Gao et al. (2016) prepared an aggregation-induced emission NP, the surface of which is modified by Tat peptide. The obtained NPs had highly efficient ability of labeling mouse bone marrow-derived MSCs, and the red emission could be detected for more than 12 passages, which were not achieved by traditional fluorescence, possessing long-term tracking and strong anti-photobleaching ability. More importantly, MSCs labeled by the NPs showed low cytotoxicity, and their viability and differentiation had no apparent influences. Lim et al. (2019) developed bicyclo nonyne (BCN)-conjugated glycol chitosan NPs (BCN-NPs) as a delivery system of dual-modal stem cell imaging probes. Yin et al. (2018) reported an organic semiconducting polymer $\mathrm{NP}\left(\mathrm{OSPN}^{+}\right)$as a PA contrast agent for tracking MSCs, utilizing a second near-infrared (NIR-II) adsorption to broaden 
the limitation of conventional inorganic PA contrast agents and the narrow range of the wavelength in the first near-infrared (NIR-I) window, shown in Figure 7. The prepared cationic NPs showed the deeper tissue imaging due to the significantly higher signal-to-noise (SNR) and enhanced the cellular uptake for human MSCs because of their good biocompatibility, appropriate size, and optimized surface property.

\section{PROBLEMS AND PROSPECTS}

Mesenchymal stem cell transplantation has been shown to be a strong potential for the treatment of CVDs. Many NPs have been fabricated and used as contrast agents by noninvasive imaging to track and monitor the transplanted MSCs, for providing more information to guide further therapy. However, one big issue associated with NPs for labeled MSCs is that NPs released from dead cells will be uptaken by macrophages, which give false-positive information in vivo. Maybe, we can label dead cells with other methods to exclude the false-positive information. Moreover, the single-imaging technique can be inefficient to meet all needs for tracking, and each of those has its own disadvantages. Although there

\section{REFERENCES}

Accomasso, L., Gallina, C., Turinetto, V., and Giachino, C. J. (2016). Stem cell tracking with nanoparticles for regenerative medicine purposes: an overview. Stem Cells Int. 2016:7920358.

Akins, E. J., and Dubey, P. (2008). Noninvasive imaging of cell-mediated therapy for treatment of cancer. J. Nucl. Med. 49, 180S-195S.

Alison, M., and Islam, S. (2009). Attributes of adult stem cells. J. Pathol. 217, 144-160. doi: 10.1002/path.2498

Alkilany, A. M., and Murphy, C. J. (2010). Toxicity and cellular uptake of gold nanoparticles: what we have learned so far? J. Nanopart Res. 12, 2313-2333. doi: 10.1007/s11051-010-9911-8

Aly, R. M. (2020). Current state of stem cell-based therapies: an overview. Stem Cell Investig. 7:8. doi: 10.21037/sci-2020-001

Andreas, K., Georgieva, R., Ladwig, M., Mueller, S., Notter, M., Sittinger, M., et al. (2012). Highly efficient magnetic stem cell labeling with citrate-coated superparamagnetic iron oxide nanoparticles for MRI tracking. Biomaterials 33, 4515-4525. doi: 10.1016/j.biomaterials.2012.02.064

Andres, R. H., Choi, R., Steinberg, G. K., and Guzman, R. (2008). Potential of adult neural stem cells in stroke therapy. Regen. Med. 3, 893-905. doi: 10.2217/ 17460751.3.6.893

Ang, L. Y., Lim, M. E., Ong, L. C., and Zhang, Y. J. N. (2011). Applications of upconversion nanoparticles in imaging, detection and therapy. Nanomedicine (Lond) 6, 1273-1288. doi: 10.2217/nnm.11.108

Babic, M., Horák, D., Trchová, M., Jendelová, P., Glogarová, K., Lesný, P., et al. (2008). Poly (L-lysine)-modified iron oxide nanoparticles for stem cell labeling. Bioconjug Chem. 19, 740-750. doi: 10.1021/bc700410z

Bailey, R. E., Smith, A. M., and Nie, S. (2004). Quantum dots in biology and medicine. Physica E: Low-dimensional Systems Nanostruct. 25, 1-12.

Barrow, M., Taylor, A., Murray, P., Rosseinsky, M. J., and Adams, D. J. (2015). Design considerations for the synthesis of polymer coated iron oxide nanoparticles for stem cell labelling and tracking using MRI. Chem. Soc. Rev. 44, 6733-6748. doi: 10.1039/c5cs00331h

Barua, S., and Mitragotri, S. (2014). Challenges associated with penetration of nanoparticles across cell and tissue barriers: a review of current status and future prospects. Nano Today 9, 223-243. doi: 10.1016/j.nantod.2014.04.008

Behlke, L. M., Lenze, E. J., and Carney, R. M. (2020). The cardiovascular effects of newer antidepressants in older adults and those with or at high risk for are some multimodal imaging techniques, more multimodal labeling agent-based NPs should be developed in the future to optimize MSC dose and delivery route for the treatment of CVDs. Importantly, the poor targeted migration and low survival rate of MSCs transplanted into the cardiovascular should be solved.

\section{AUTHOR CONTRIBUTIONS}

$\mathrm{HH}$ completed the first draft of the manuscript. XD, ZH, and ZY offered the excellent advices and perfected the first draft. WH improved the first draft and finally finished the manuscript and provided the support of funds. All authors contributed to the article and approved the submitted version.

\section{FUNDING}

This work was supported by the Sanming Project of Medicine in Shenzhen (No. SZSM201911007), Key Laboratory of Emergency and Trauma (Hainan Medical University), and Ministry of Education (Grant No. KLET-201905).

cardiovascular diseases. CNS Drugs 34, 1133-1147. doi: 10.1007/s40263-02000763-z

Behzadi, S., Serpooshan, V., Tao, W., Hamaly, M. A., Alkawareek, M. Y., Dreaden, E. C., et al. (2017). Cellular uptake of nanoparticles: journey inside the cell. Chem. Soc. Rev. 46, 4218-4244. doi: 10.1039/c6cs00636a

Bellin, M.-F. (2006). MR contrast agents, the old and the new. Eur. J. Radiol. 60, 314-323. doi: 10.1016/j.ejrad.2006.06.021

Betzer, O., Meir, R., Motiei, M., Yadid, G., and Popovtzer, R. (2017). "Gold nanoparticle-cell labeling methodology for tracking stem cells within the brain," in Proceedings of the Nanoscale Imaging, Sensing, and Actuation for Biomedical Applications XIV: International Society for Optics and Photonics, (Bellingham, DC: SPIE).

Betzer, O., Shwartz, A., Motiei, M., Kazimirsky, G., Gispan, I., Damti, E., et al. (2014). Nanoparticle-based CT imaging technique for longitudinal and quantitative stem cell tracking within the brain: application in neuropsychiatric disorders. ACS Nano 8, 9274-9285. doi: 10.1021/nn503131h

Bhirde, A., Xie, J., Swierczewska, M., and Chen, X. J. N. (2011). Nanoparticles for cell labeling. Nanoscale 3, 142-153.

Bull, E., Madani, S. Y., Sheth, R., Seifalian, A., Green, M., and Seifalian, A. M. (2014). Stem cell tracking using iron oxide nanoparticles. Int. J. Nanomed. 9:1641. doi: $10.2147 /$ ijn.s48979

Bulte, J. W. J. R. (2017). Science to practice: can MR imaging cell tracking of macrophage infiltration be used as a predictive imaging biomarker for transplanted stem cell rejection? Radiology 284, 307-309. doi: 10.1148/radiol. 2017170536

Cahill, K. S., Gaidosh, G., Huard, J., Silver, X., Byrne, B. J., and Walter, G. A. J. T. (2004). Noninvasive monitoring and tracking of muscle stem cell transplants. Transplantation 78, 1626-1633. doi: 10.1097/01.tp.0000145528.51525.8b

Cai, W. W., Wang, L. J., Li, S. J., Zhang, X. P., Li, T. T., Wang, Y. H., et al. (2017). Effective tracking of bone mesenchymal stem cells in vivo by magnetic resonance imaging using melanin-based gadolinium3+ nanoparticles. J. Biomed. Mater. Res. A 105, 131-137. doi: 10.1002/jbm.a.35891

Calero, M., Gutiérrez, L., Salas, G., Luengo, Y., Lázaro, A., Acedo, P., et al. (2014). Efficient and safe internalization of magnetic iron oxide nanoparticles: two fundamental requirements for biomedical applications. Nanomedicine 10, 733-743. doi: 10.1016/j.nano.2013.11.010

Caplan, A. I. (2009). Why are MSCs therapeutic? new data: new insight. J. Pathol. 217, 318-324. doi: 10.1002/path.2469 
Caplan, A. I. (2017). Mesenchymal stem cells: time to change the name! Stem Cells Transl. Med. 6, 1445-1451. doi: 10.1002/sctm.17-0051

Carella, A. M., Cavaliere, M., Lerma, E., Ferrara, R., Tedeschi, L., Romanelli, A., et al. (2000). Autografting followed by nonmyeloablative immunosuppressive chemotherapy and allogeneic peripheral-blood hematopoietic stem-cell transplantation as treatment of resistant Hodgkin's disease and non-Hodgkin's lymphoma. J. Clin. Oncol. 18, 3918-3924. doi: 10.1200/jco.2000.18.23.3918

Chan, K. Y., Jang, M. J., Yoo, B. B., Greenbaum, A., Ravi, N., Wu, W.-L., et al. (2017). Engineered AAVs for efficient noninvasive gene delivery to the central and peripheral nervous systems. Nat. Neurosci. 20,1172-1179. doi: 10.1038/nn. 4593

Chandran, P., Riviere, J. E., and Monteiro-Riviere, N. A. J. N. (2017). Surface chemistry of gold nanoparticles determines the biocorona composition impacting cellular uptake, toxicity and gene expression profiles in human endothelial cells. Nanotoxicology 11, 507-519. doi: 10.1080/17435390.2017. 1314036

Chen, F., and Jokerst, J. V. (2020). Stem cell tracking with nanoparticle-based ultrasound contrast agents. Methods Mol. Biol. 2126, 141-153. doi: 10.1007/ 978-1-0716-0364-2_13

Chen, F., Zhao, E. R., Hu, T., Shi, Y., Sirbuly, D. J., and Jokerst, J. V. (2019). Silicon carbide nanoparticles as a photoacoustic and photoluminescent dual-imaging contrast agent for long-term cell tracking. Nanoscale Adv. 1, 3514-3520. doi: 10.1039/c9na00237e

Chen, G., Tian, F., Li, C., Zhang, Y., Weng, Z., Zhang, Y., et al. (2015). In vivo real-time visualization of mesenchymal stem cells tropism for cutaneous regeneration using NIR-II fluorescence imaging. Biomaterials 53, 265-273. doi: 10.1016/j.biomaterials.2015.02.090

Chen, X., Peng, D., Ju, Q., and Wang, F. J. (2015). Photon upconversion in core-shell nanoparticles. Chem. Soc. Rev. 44, 1318-1330.

Chen, X., Tian, F., Zhang, X., and Wang, W. J. (2013). Internalization pathways of nanoparticles and their interaction with a vesicle. Soft Matter. 9, 7592-7600. doi: $10.1039 / \mathrm{c} 3 \mathrm{sm} 50931 \mathrm{a}$

Cheng, L., Wang, C., Ma, X., Wang, Q., Cheng, Y., Wang, H., et al. (2013). Multifunctional upconversion nanoparticles for dual-modal imaging-guided stem cell therapy under remote magnetic control. Adv. Functional. Mater. 23, 272-280. doi: 10.1002/adfm.201201733

Cheng, S.-H., Yu, D., Tsai, H.-M., Morshed, R. A., Kanojia, D., Lo, L.-W., et al. (2016). Dynamic in vivo SPECT imaging of neural stem cells functionalized with radiolabeled nanoparticles for tracking of glioblastoma. J. Nucl. Med. 57, 279-284. doi: 10.2967/jnumed.115.163006

Chetty, S. S., Praneetha, S., Govarthanan, K., Verma, R. S., and Vadivel Murugan, A. J. (2019). Noninvasive tracking and regenerative capabilities of transplanted human umbilical cord-derived mesenchymal stem cells labeled with I-III-IV semiconducting nanocrystals in liver-injured living mice. ACS Appl. Mater. Interfaces 11, 8763-8778. doi: 10.1021/acsami.8b19953

Cosgrove, D. J. (2006). Ultrasound contrast agents: an overview. Eur. J. Radiol. 60, 324-330. doi: 10.1016/j.ejrad.2006.06.022

Crabbe, A., Vandeputte, C., Dresselaers, T., Sacido, A. A., Verdugo, J. M. G., Eyckmans, J., et al. (2010). Effects of MRI contrast agents on the stem cell phenotype. Cell Transplant 19, 919-936. doi: 10.3727/096368910x494623

Cui, Z., Yang, B., and Li, R.-K. (2016). Application of biomaterials in cardiac repair and regeneration. Engineering 2, 141-148. doi: 10.1016/j.eng.2016.01.028

Davis, W. C. (1972). H-2 antigen on cell membranes: an explanation for the alteration of distribution by indirect labeling techniques. Science 175, 10061008. doi: $10.1126 /$ science. 175.4025 .1006

Deng, Y., Zhang, X., Shen, H., He, Q., Wu, Z., Liao, W., et al. (2020). Application of the nano-drug delivery system in treatment of cardiovascular diseases. Front. Bioeng. Biotechnol. 7:489. doi: 10.3389/fbioe.2019.00489

Dhada, K. S., Hernandez, D. S., and Suggs, L. J. (2019). In vivo photoacoustic tracking of mesenchymal stem cell viability. ACS Nano 13, 7791-7799. doi: 10.1021/acsnano. 9 b01802

Diekman, B. O., and Guilak, F. J. (2013). Stem cell-based therapies for osteoarthritis: challenges and opportunities. Curr. Opin. Rheumatol. 25:119. doi: 10.1097/bor.0b013e32835aa28d

DiPersio, J. F., Stadtmauer, E. A., Nademanee, A., Micallef, I. N., Stiff, P. J., Kaufman, J. L., et al. (2009). Plerixafor and G-CSF versus placebo and G-CSF to mobilize hematopoietic stem cells for autologous stem cell transplantation in patients with multiple myeloma. Blood 113, 5720-5726. doi: 10.1182/blood2008-08-174946

Donnelly, E. M., Kubelick, K. P., Dumani, D. S., and Emelianov, S. Y. (2018). Photoacoustic image-guided delivery of plasmonic-nanoparticlelabeled mesenchymal stem cells to the spinal cord. Nano Lett. 18, 6625-6632. doi: 10.1021/acs.nanolett.8b03305

Edmundson, M., Thanh, N. T., and Song, B. J. T. (2013). Nanoparticles based stem cell tracking in regenerative medicine. Theranostics 3, 573-582. doi: 10.7150/ thno. 5477

Elkhenany, H., Abd Elkodous, M., Ghoneim, N. I., Ahmed, T. A., Ahmed, S. M., Mohamed, I. K., et al. (2020). Comparison of different uncoated and starchcoated superparamagnetic iron oxide nanoparticles: implications for stem cell tracking. Int. J. Biol. Macromol. 143, 763-774. doi: 10.1016/j.ijbiomac.2019.10. 031

Ferreira, L. J. (2009). Nanoparticles as tools to study and control stem cells. J. Cell Biochem. 108, 746-752. doi: 10.1002/jcb.22303

Friedenstein, A., Chailakhjan, R., and Lalykina, K. (1970). The development of fibroblast colonies in monolayer cultures of guinea-pig bone marrow and spleen cells. Cell Prolif. 3, 393-403. doi: 10.1111/j.1365-2184.1970.tb00347.x

Fu, Y., Azene, N., Xu, Y., and Kraitchman, D. L. (2011). Tracking stem cells for cardiovascular applications in vivo: focus on imaging techniques. Imag. Med. 3 , 473-486. doi: 10.2217/iim.11.33

Gao, M., Chen, J., Lin, G., Li, S., Wang, L., Qin, A., et al. (2016). Long-term tracking of the osteogenic differentiation of mouse BMSCs by aggregationinduced emission nanoparticles. ACS Appl. Mater. 8, 17878-17884. doi: 10. 1021/acsami.6b05471

Gao, Y., Cui, Y., Chan, J. K., and Xu, C. J. (2013). Stem cell tracking with optically active nanoparticles. Am. J. Nucl. Med. Mol. Imag. 3, 232-246.

Giljohann, D. A., Seferos, D. S., Daniel, W. L., Massich, M. D., Patel, P. C., and Mirkin, C. A. (2010). Gold nanoparticles for biology and medicine. Angew Chem. Int. Ed Engl. 49, 3280-3294.

Gliga, A. R., Skoglund, S., Wallinder, I. O., Fadeel, B., and Karlsson, H. L. (2014). Size-dependent cytotoxicity of silver nanoparticles in human lung cells: the role of cellular uptake, agglomeration and Ag release. Part Fibre Toxicol. 11:11. doi: 10.1186/1743-8977-11-11

Godin, B., Sakamoto, J. H., Serda, R. E., Grattoni, A., Bouamrani, A., and Ferrari, M. J. (2010). Emerging applications of nanomedicine for the diagnosis and treatment of cardiovascular diseases. Trends Pharmacol. Sci. 31, 199-205. doi: 10.1016/j.tips.2010.01.003

Goradel, N. H., Hour, F. G., Negahdari, B., Malekshahi, Z. V., Hashemzehi, M., Masoudifar, A., et al. (2018). Stem cell therapy: a new therapeutic option for cardiovascular diseases. J. Cell Biochem. 119, 95-104. doi: 10.1002/jcb.26169

Grauss, R. W., Winter, E. M., van Tuyn, J., Pijnappels, D. A., Steijn, R. V., Hogers, B., et al. (2007). Mesenchymal stem cells from ischemic heart disease patients improve left ventricular function after acute myocardial infarction. Am. J. Physiol. Heart Circ. Physiol. 293, H2438-H2447.

Gu, L., Li, X., Jiang, J., Guo, G., Wu, H., Wu, M., et al. (2018). Stem cell tracking using effective self-assembled peptide-modified superparamagnetic nanoparticles. Nanoscale 10, 15967-15979. doi: 10.1039/c7nr 07618e

Guldris, N., Argibay, B. R., Gallo, J., Iglesias-Rey, R. N., Carbo-Argibay, E., Kolen'ko, Y. V., et al. (2017). Magnetite nanoparticles for stem cell labeling with high efficiency and long-term in vivo tracking. Bioconjugate Chem. 28, 362-370. doi: 10.1021/acs.bioconjchem.6b00522

Guo, B., Chen, J., Chen, N., Middha, E., Xu, S., Pan, Y., et al. (2019a). High-Resolution 3D NIR-II photoacoustic imaging of cerebral and tumor vasculatures using conjugated polymer nanoparticles as contrast agent. $A d v$. Mater. 31:1808355. doi: 10.1002/adma.201808355

Guo, B., Feng, Z., Hu, D., Xu, S., Middha, E., Pan, Y., et al. (2019b). Precise deciphering of brain vasculatures and microscopic tumors with dual NIR-II fluorescence and photoacoustic imaging. Adv. Mater. 31:1902504. doi: 10.1002/ adma.201902504

Guo, Y., Yu, Y., Hu, S., Chen, Y., and Shen, Z. J. (2020). The therapeutic potential of mesenchymal stem cells for cardiovascular diseases. J. Mol. Endocrinol. 11, R109-R120.

Hachani, R., Birchall, M. A., Lowdell, M. W., Kasparis, G., Tung, L. D., Manshian, B. B., et al. (2017). Assessing cell-nanoparticle interactions by high content 
imaging of biocompatible iron oxide nanoparticles as potential contrast agents for magnetic resonance imaging. Sci. Rep. 7:7850.

Hahn, M. A., Singh, A. K., Sharma, P., Brown, S. C., and Moudgil, B. M. (2011). Nanoparticles as contrast agents for in-vivo bioimaging: current status and future perspectives. Anal. Bioanal. Chem. 399, 3-27. doi: 10.1007/s00216-010$4207-5$

Hao, J., Zhu, W., Sheng, C., Yu, Y., and Zhou, Q. J. (2009). Human parthenogenetic embryonic stem cells: one potential resource for cell therapy. Sci. China C Life Sci. 52, 599-602. doi: 10.1007/s11427-009-0096-2

Hao, L., Zou, Z., Tian, H., Zhang, Y., Zhou, H., and Liu, L. J. (2014). Stem cell-based therapies for ischemic stroke. Biomed. Res. Int. 2014:468748.

Herschman, H. R. (2004). PET reporter genes for noninvasive imaging of gene therapy, cell tracking and transgenic analysis. Crit. Rev. Oncol. Hematol. 51, 191-204. doi: 10.1016/j.critrevonc.2004.04.006

Heslop, J. A., Hammond, T. G., Santeramo, I., Tort Piella, A., Hopp, I., Zhou, J., et al. (2015). Concise review: workshop review: understanding and assessing the risks of stem cell-based therapies. Stem Cells Transl. Med. 4, 389-400.

Hong, H., Yang, Y., Zhang, Y., and Cai, W. J. (2010). Non-invasive cell tracking in cancer and cancer therapy. Curr. Top Med. Chem. 10, 1237-1248. doi: $10.2174 / 156802610791384234$

Hsiao, J. K., Tsai, C. P., Chung, T. H., Hung, Y., Yao, M., Liu, H. M., et al. (2008). Mesoporous silica nanoparticles as a delivery system of gadolinium for effective human stem cell tracking. Small 4, 1445-1452. doi: 10.1002/smll.200701316

Hsieh, S.-C., Wang, F.-F., Lin, C.-S., Chen, Y.-J., Hung, S.-C., and Wang, Y.-J. (2006). The inhibition of osteogenesis with human bone marrow mesenchymal stem cells by CdSe/ZnS quantum dot labels. Biomaterials 27, 1656-1664. doi: 10.1016/j.biomaterials.2005.09.004

Huang, D. M., Hung, Y., Ko, B. S., Hsu, S. C., Chen, W. H., Chien, C. L., et al. (2005). Highly efficient cellular labeling of mesoporous nanoparticles in human mesenchymal stem cells: implication for stem cell tracking. FASEB J. 19, 2014-2016. doi: 10.1096/fj.05-4288fje

Huang, J., Ning, X., Luo, W., Chen, M., Wang, Z., Zhang, W., et al. (2020). CT/NIRF dual-modal imaging tracking and therapeutic efficacy of transplanted mesenchymal stem cells labeled with $\mathrm{Au}$ nanoparticles in silica-induced pulmonary fibrosis. J. Mater. Chem. B 8, 1713-1727. doi: 10.1039/c9tb02652e

Idris, N. M., Li, Z., Ye, L., Sim, E. K. W., Mahendran, R., Ho, P. C.-L., et al. (2009). Tracking transplanted cells in live animal using upconversion fluorescent nanoparticles. Biomaterials 30, 5104-5113. doi: 10.1016/j.biomaterials.2009.05. 062

Jaiswal, J. K., Goldman, E. R., Mattoussi, H., and Simon, S. M. (2004). Use of quantum dots for live cell imaging. Nat. Methods 1, 73-78. doi: 10.1038/ nmeth1004-73

Jaiswal, S., Jamieson, C. H., Pang, W. W., Park, C. Y., Chao, M. P., Majeti, R., et al. (2009). CD47 is upregulated on circulating hematopoietic stem cells and leukemia cells to avoid phagocytosis. Cell 138, 271-285. doi: 10.1016/j.cell.2009. 05.046

Jambhrunkar, S., Qu, Z., Popat, A., Yang, J., Noonan, O., Acauan, L., et al. (2014). Effect of surface functionality of silica nanoparticles on cellular uptake and cytotoxicity. Mol. Pharm. 11, 3642-3655. doi: 10.1021/mp500385n

Jiang, R., Liao, Y., Yang, F., Cheng, Y., Dai, X., and Chao, J. J. (2019). SPIO nanoparticle-labeled bone marrow mesenchymal stem cells inhibit pulmonary EndoMT induced by SiO2. Exp. Cell Res. 383:111492. doi: 10.1016/j.yexcr.2019. 07.005

Jing, X.-H., Yang, L., Duan, X.-J., Xie, B., Chen, W., Li, Z., et al. (2008). In vivo MR imaging tracking of magnetic iron oxide nanoparticle labeled, engineered, autologous bone marrow mesenchymal stem cells following intra-articular injection. Joint Bone Spine 75, 432-438. doi: 10.1016/j.jbspin.2007.09.013

Kang, H., Zhang, K., Pan, Q., Lin, S., Wong, D. S. H., Li, J., et al. (2018). Remote control of intracellular calcium using upconversion nanotransducers regulates stem cell differentiation in vivo. Adv. Funct. Mater. 28:1802642. doi: 10.1002/ adfm.201802642

Kastrup, J. J. (2011). Stem cells therapy for cardiovascular repair in ischemic heart disease: how to predict and secure optimal outcome? EPMA J. 2, 107-117. doi: 10.1007/s13167-011-0062-5

Khan, I., Saeed, K., and Khan, I. J. (2019). Nanoparticles: Properties, applications and toxicities. Arabian J. Chem. 12, 908-931. doi: 10.1016/j.arabjc.2017 .05 .011
Kim, H., Dae, H.-M., Park, C., Kim, E. O., Kim, D., Kim, I.-H., et al. (2011). A highly sensitive magnetite nanoparticle as a simple and rapid stem cell labelling agent for MRI tracking. J. Mater. Chem. 21, 7742-7747. doi: 10.1039/c1jm10247h

Kim, J., Shapiro, L., and Flynn, A. J. (2015a). The clinical application of mesenchymal stem cells and cardiac stem cells as a therapy for cardiovascular disease. Pharmacol Ther. 151, 8-15. doi: 10.1016/j.pharmthera.2015.02.003

Kim, K. S., Park, W., and Na, K. J. B. (2015b). Gadolinium-chelate nanoparticle entrapped human mesenchymal stem cell via photochemical internalization for cancer diagnosis. Biomaterials 36, 90-97. doi: 10.1016/j.biomaterials.2014.09. 014

Kim, M. H., Lee, Y. J., and Kang, J. H. (2016a). Stem cell monitoring with a direct or indirect labeling method. Nucl. Med. Mol. Imag. 50, 275-283. doi: 10.1007/s13139-015-0380-y

Kim, S. J., Lewis, B., Steiner, M. S., Bissa, U. V., Dose, C., Frank, J. A., et al. (2016b). Superparamagnetic iron oxide nanoparticles for direct labeling of stem cells and in vivo MRI tracking. Contrast Media Mol. Imag. 11, 55-64. doi: 10.1002/cmmi. 1658

Kircher, M. F., Gambhir, S. S., and Grimm, J. J. (2011). Noninvasive cell-tracking methods. Nat. Rev. Clin. Oncol. 8:677.

Kraitchman, D. L., and Bulte, J. W. J. A. (2009). In vivo imaging of stem cells and beta cells using direct cell labeling and reporter gene methods. Arterioscler Thromb Vasc. Biol. 29, 1025-1030. doi: 10.1161/atvbaha.108.165571

Krebsbach, P. H., and Robey, P. G. (2002). Dental and skeletal stem cells: potential cellular therapeutics for craniofacial regeneration. J. Dent Educ. 66, 766-773. doi: 10.1002/j.0022-0337.2002.66.6.tb03557.x

Laffey, M. K., Kubelick, K. P., Donnelly, E. M., and Emelianov, S. Y. (2020). Effects of freezing on mesenchymal stem cells labeled with gold nanoparticles. Tissue Eng. Part C Methods 26, 1-10. doi: 10.1089/ten.tec.2019.0198

Lankoff, A., Arabski, M., Wegierek-Ciuk, A., Kruszewski, M., Lisowska, H., Banasik-Nowak, A., et al. (2012). Effect of surface modification of silica nanoparticles on toxicity and cellular uptake by human peripheral blood lymphocytes in vitro. Nanotoxicology 7, 235-250. doi: 10.3109/17435390.2011. 649796

Lee, H., Park, I., Kim, H., and Kim, S. J. (2009). Human neural stem cells overexpressing glial cell line-derived neurotrophic factor in experimental cerebral hemorrhage. Gene Ther. 16, 1066-1076. doi: 10.1038/gt.2009.51

Lee, S. H., Park, D. J., Yun, W. S., Park, J.-E., Choi, J. S., Key, J., et al. (2020). Endocytic trafficking of polymeric clustered superparamagnetic iron oxide nanoparticles in mesenchymal stem cells. J. Control. Release 326, 408-418. doi: 10.1016/j.jconrel.2020.07.032

Lee, S.-T., Chu, K., Park, J.-E., Lee, K., Kang, L., Kim, S. U., et al. (2005). Intravenous administration of human neural stem cells induces functional recovery in Huntington's disease rat model. Neurosci. Res. 52, 243-249. doi: 10.1016/j. neures.2005.03.016

Lewandowska-Łańcucka, J., Staszewska, M., Szuwarzyński, M., Kêpczyński, M., Romek, M., Tokarz, W., et al. (2014). Synthesis and characterization of the superparamagnetic iron oxide nanoparticles modified with cationic chitosan and coated with silica shell. J. Alloys Compounds 586, 45-51. doi: 10.1016/j. jallcom.2013.10.039

Lewin, M., Carlesso, N., Tung, C.-H., Tang, X.-W., Cory, D., Scadden, D. T., et al. (2000). Tat peptide-derivatized magnetic nanoparticles allow in vivo tracking and recovery of progenitor cells. Nat. Biotechnol. 18, 410-414. doi: 10.1038/ 74464

Li, J., Lee, W. Y., Wu, T., Xu, J., Zhang, K., Li, G., et al. (2016). Multifunctional quantum dot nanoparticles for effective differentiation and long-term tracking of human mesenchymal stem cells in vitro and in vivo. Adv. Healthc. Mater. 5, 1049-1057. doi: 10.1002/adhm.201500879

Li, L., Jiang, W., Luo, K., Song, H., Lan, F., Wu, Y., et al. (2013). Superparamagnetic iron oxide nanoparticles as MRI contrast agents for non-invasive stem cell labeling and tracking. Theranostics 3, 595-615. doi: 10.7150/thno.5366

Li, Y., He, J., Wang, F., Ju, Z., Liu, S., Zhang, Y., et al. (2010). Differentiation of embryonic stem cells in adult bone marrow. J. Genet. Genomics 37, 431-439.

Li, Y., Song, Y., Zhao, L., Gaidosh, G., Laties, A. M., and Wen, R. J. (2008). Direct labeling and visualization of blood vessels with lipophilic carbocyanine dye DiI. Nat. Protoc. 3, 1703-1708. doi: 10.1038/nprot.2008.172

Liang, C., Wang, C., and Liu, Z. J. P. (2013). Stem cell labeling and tracking with nanoparticles. Stem Cells Int. 30, 1006-1017. 
Liao, N., Wu, M., Pan, F., Lin, J., Li, Z., Zhang, D., et al. (2016). Poly (dopamine) coated superparamagnetic iron oxide nanocluster for noninvasive labeling, tracking, and targeted delivery of adipose tissue-derived stem cells. Sci. Rep. 6:18746.

Lilly, M. A., Davis, M. F., Fabie, J. E., Terhune, E. B., and Gallicano, G. I. (2016). Current stem cell based therapies in diabetes. Am. J. Stem Cells 5, 87-98.

Lim, S., Yoon, H. Y., Jang, H. J., Song, S., Kim, W., Park, J., et al. (2019). Dual-modal imaging-guided precise tracking of bioorthogonally labeled mesenchymal stem cells in mouse brain stroke. ACS Nano 13, 10991-11007. doi: 10.1021/acsnano. $9 \mathrm{~b} 02173$

Lin, W. (2015). Introduction: Nanoparticles in Medicine. Washington, DC: ACS Publications.

Liu, G., Wang, Z., Lu, J., Xia, C., Gao, F., Gong, Q., et al. (2011). Low molecular weight alkyl-polycation wrapped magnetite nanoparticle clusters as MRI probes for stem cell labeling and in vivo imaging. Biomaterials 32, 528-537. doi: 10.1016/j.biomaterials.2010.08.099

Loewen, N., Fautsch, M. P., Teo, W.-L., Bahler, C. K., Johnson, D. H., Poeschla, E. M., et al. (2004). Long-term, targeted genetic modification of the aqueous humor outflow tract coupled with noninvasive imaging of gene expression in vivo. Invest. Ophthalmol. Vis. Sci. 45, 3091-3098. doi: 10.1167/iovs.04-0366

Lu, C.-W., Hung, Y., Hsiao, J.-K., Yao, M., Chung, T.-H., Lin, Y.-S., et al. (2007). Bifunctional magnetic silica nanoparticles for highly efficient human stem cell labeling. Nano Lett. 7, 149-154. doi: 10.1021/nl0624263

Lusic, H., and Grinstaff, M. W. (2013). X-ray-computed tomography contrast agents. Chem. Rev. 113, 1641-1666. doi: 10.1021/cr200358s

Lv, F.-J., Tuan, R. S., Cheung, K. M., and Leung, V. Y. (2014). Concise review: the surface markers and identity of human mesenchymal stem cells. Stem Cells 32, 1408-1419. doi: 10.1002/stem.1681

Ma, Y., Ji, Y., You, M., Wang, S., Dong, Y., Jin, G., et al. (2016). Labeling and long-term tracking of bone marrow mesenchymal stem cells in vitro using NaYF4: Yb3+, Er3+ upconversion nanoparticles. Acta Biomater. 42, 199-208. doi: 10.1016/j.actbio.2016.07.030

Mahmoudi, M., Sant, S., Wang, B., Laurent, S., and Sen, T. J. (2011). Superparamagnetic iron oxide nanoparticles (SPIONs): development, surface modification and applications in chemotherapy. Adv. Drug Delivery Rev. 63, 24-46. doi: 10.1016/j.addr.2010.05.006

Maumus, M., Guérit, D., Toupet, K., Jorgensen, C., and Noël, D. J. (2011). Mesenchymal stem cell-based therapies in regenerative medicine: applications in rheumatology. Stem Cells Res. Ther. 2:14. doi: 10.1186/scrt55

Mazumder, S., Dey, R., Mitra, M., Mukherjee, S., and Das, G. J. (2009). Biofunctionalized quantum dots in biology and medicine. J. Nanomaterials 2009:815734.

McNamara, K., and Tofail, S. A. (2017). Nanoparticles in biomedical applications. Adv. Phys. 2, 54-88.

Meir, R., and Popovtzer, R. J. (2018). Cell tracking using gold nanoparticles and computed tomography imaging. Wiley Interdiscip. Rev. Nanomed. Nanobiotechnol. 10:e1480. doi: 10.1002/wnan.1480

Miguel, O. B., Gossuin, Y., Morales, M., Gillis, P., Muller, R., and VeintemillasVerdaguer, S. J. (2007). Comparative analysis of the $1 \mathrm{H}$ NMR relaxation enhancement produced by iron oxide and core-shell iron-iron oxide nanoparticles. Magn. Reson. Imaging 25, 1437-1441. doi: 10.1016/j.mri.2007. 04.006

Mikkola, H. K., and Orkin, S. H. J. D. (2006). The journey of developing hematopoietic stem cells. Development 133, 3733-3744. doi: 10.1242/dev.02568

Murphy, C. J., Gole, A. M., Stone, J. W., Sisco, P. N., Alkilany, A. M., Goldsmith, E. C., et al. (2008). Gold nanoparticles in biology: beyond toxicity to cellular imaging. Acc. Chem. Res. 41, 1721-1730. doi: 10.1021/ar80 $0035 \mathrm{u}$

Na, H. B., and Hyeon, T. J. (2009). Nanostructured T1 MRI contrast agents. J. Mater. Chem. 19, 6267-6273. doi: 10.1039/b902685a

Nafiujjaman, M., and Kim, T. (2020). Gold nanoparticles as a computed tomography marker for stem cell tracking. Methods Mol. Biol. 2126, 155-166. doi: 10.1007/978-1-0716-0364-2_14

Ni, Z., and Chen, R. (2015). Transcranial magnetic stimulation to understand pathophysiology and as potential treatment for neurodegenerative diseases. Transl. Neurodegener. 4:22. doi: 10.1186/s40035-015-0045-x

Park, W., Yang, H. N., Ling, D., Yim, H., Kim, K. S., Hyeon, T., et al. (2014). Multi-modal transfection agent based on monodisperse magnetic nanoparticles for stem cell gene delivery and tracking. Biomaterials 35, 7239-7247. doi: 10.1016/j.biomaterials.2014.05.010

Patrick, P. S., Kolluri, K. K., Thin, M. Z., Edwards, A., Sage, E. K., Sanderson, T., et al. (2020). Lung delivery of MSCs expressing anti-cancer protein TRAIL visualised with $89 \mathrm{Zr}$-oxine PET-CT. Stem Cell Res. Ther. 11:256.

Peng, X., Li, C., Bai, Y., Wang, X., Zhang, Y., An, Y., et al. (2018). Noninvasive evaluation of the migration effect of transplanted endothelial progenitor cells in ischemic muscle using a multimodal imaging agent. Int. J. Nanomed. 13, 1819-1829. doi: 10.2147/ijn.s152976

Perez, J. R., Ybarra, N., Chagnon, F., Serban, M., Lee, S., Seuntjens, J., et al. (2017). Tracking of mesenchymal stem cells with fluorescence endomicroscopy imaging in radiotherapy-induced lung injury. Sci. Rep. 7:40748.

Ratzinger, G., Agrawal, P., Körner, W., Lonkai, J., Sanders, H. M., Terreno, E., et al. (2010). Surface modification of PLGA nanospheres with Gd-DTPA and Gd-DOTA for high-relaxivity MRI contrast agents. Biomaterials 31, 8716-8723. doi: 10.1016/j.biomaterials.2010.07.095

Rawat, S., Gupta, S., Bhat, M., Dinda, A. K., and Mohanty, S. (2019). Efficient labeling of human mesenchymal stem cells using iron oxide nanoparticles. Methods Mol. Biol. 2150, 113-120. doi: 10.1007/7651_2019_265

Ren, N., Liang, N., Yu, X., Wang, A., Xie, J., and Sun, C. J. N. (2020). Ligandfree upconversion nanoparticles for cell labeling and their effects on stem cell differentiation. Nanotechnology 31:145101. doi: 10.1088/1361-6528/ab62cc

Rhyner, M. N., Smith, A. M., Gao, X., Mao, H., Yang, L., and Nie, S. (2006). Quantum dots and multifunctional nanoparticles: new contrast agents for tumor imaging. Nanomedicine 1, 209-217. doi: 10.2217/17435889.1.2.209

Riera, R., Feiner-Gracia, N., Fornaguera, C., Cascante, A., Borrós, S., and Albertazzi, L. J. N. (2019). Tracking the DNA complexation state of PBAE polyplexes in cells with super resolution microscopy. Nanoscale 11, 1786917877. doi: 10.1039/c9nr02858g

Robert, P., Lehericy, S., Grand, S., Violas, X., Fretellier, N., Idée, J.-M., et al. (2015). T1-weighted hypersignal in the deep cerebellar nuclei after repeated administrations of gadolinium-based contrast agents in healthy rats: difference between linear and macrocyclic agents. Invest. Radiol. 50, 473-480. doi: 10. 1097/rli.0000000000000181

Saha, K., Kim, S. T., Yan, B., Miranda, O. R., Alfonso, F. S., Shlosman, D., et al. (2013). Surface functionality of nanoparticles determines cellular uptake mechanisms in mammalian cells. Small 9, 300-305. doi: 10.1002/smll. 201201129

Santelli, J., Lechevallier, S., Baaziz, H., Vincent, M., Martinez, C., Mauricot, R., et al. (2018). Multimodal gadolinium oxysulfide nanoparticles: a versatile contrast agent for mesenchymal stem cell labeling. Nanoscale 10, 16775-16786. doi: $10.1039 / \mathrm{c} 8 \mathrm{nr} 03263 \mathrm{~g}$

Santoso, M. R., and Yang, P. C. (2016). Magnetic nanoparticles for targeting and imaging of stem cells in myocardial infarction. Stem Cells Int. 2016:4198790.

Schmitz, N., Pfistner, B., Sextro, M., Sieber, M., Carella, A. M., Haenel, M., et al. (2002). Aggressive conventional chemotherapy compared with highdose chemotherapy with autologous haemopoietic stem-cell transplantation for relapsed chemosensitive Hodgkin's disease: a randomised trial. Lancet 359, 2065-2071. doi: 10.1016/S0140-6736(02)08938-9

Sehl, O. C., Makela, A. V., Hamilton, A. M., and Foster, P. J. (2019). Trimodal cell tracking in vivo: combining iron-and fluorine-based magnetic resonance imaging with magnetic particle imaging to monitor the delivery of mesenchymal stem cells and the ensuing inflammation. Tomography 5, 367-376. doi: 10.18383/j.tom.2019.00020

Seleverstov, O., Zabirnyk, O., Zscharnack, M., Bulavina, L., Nowicki, M., Heinrich, J.-M., et al. (2006). Quantum dots for human mesenchymal stem cells labeling. a size-dependent autophagy activation. Nano Lett. 6, 2826-2832. doi: 10.1021/ nl0619711

Shah, B. S., Clark, P. A., Moioli, E. K., Stroscio, M. A., and Mao, J. J. (2007). Labeling of mesenchymal stem cells by bioconjugated quantum dots. Nano Lett. 7, 3071-3079. doi: 10.1021/nl071547f

Shang, Y., Li, T., and Yu, G. J. (2017). Clinical applications of near-infrared diffuse correlation spectroscopy and tomography for tissue blood flow monitoring and imaging. Physiol. Meas. 38, R1-R26. doi: 10.1088/1361-6579/aa60b7

Sherry, A. D., Cacheris, W. P., and Kuan, K. T. (1988). Stability constants for Gd3+ binding to model DTPA-conjugates and DTPA-proteins: implications for their use as magnetic resonance contrast agents. Magn. Reson. Med. 8, 180-190. doi: $10.1002 / \mathrm{mrm} .1910080208$ 
Shin, T. H., Lee, D. Y., Ketebo, A. A., Lee, S., Manavalan, B., Basith, S., et al. (2019). Silica-coated magnetic nanoparticles decrease human bone marrow-derived mesenchymal stem cell migratory activity by reducing membrane fluidity and impairing focal adhesion. Nanomaterials 9:1475. doi: 10.3390/nano9101475

Singh, N., Jenkins, G. J., Asadi, R., and Doak, S. H. (2010). Potential toxicity of superparamagnetic iron oxide nanoparticles (SPION). Nano Rev. 1:5358. doi: 10.3402/nano.v1i0.5358

Srivastava, D., and Ivey, K. N. (2006). Potential of stem-cell-based therapies for heart disease. Nature 441, 1097-1099. doi: 10.1038/nature04961

Stenudd, M., Sabelström, H., and Frisén, J. J. (2015). Role of endogenous neural stem cells in spinal cord injury and repair. JAMA Neurol. 72, 235-237. doi: 10.1001/jamaneurol.2014.2927

Su, X., Shen, Y., Weintraub, N. L., and Tang, Y. (2019). Imaging and tracking stem cell engraftment in ischemic hearts by near-infrared fluorescent protein (iRFP) labeling. Methods Mol. Biol. 2150, 121-129. doi: 10.1007/7651_2019_226

Sutton, E. J., Henning, T. D., Pichler, B. J., Bremer, C., and Daldrup-Link, H. E. (2008). Cell tracking with optical imaging. Eur. Radiol. 18, 2021-2032. doi: 10.1007/s00330-008-0984-z

Szpak, A., Kania, G., Skórka, T., Tokarz, W., Zapotoczny, S., and Nowakowska, M. J. (2013). Stable aqueous dispersion of superparamagnetic iron oxide nanoparticles protected by charged chitosan derivatives. J. Nanopart. Res. 15:1372. doi: 10.1007/s11051-012-1372-9

Temple, S. J. (2001). The development of neural stem cells. Nature 414, 112-117. doi: $10.1038 / 35102174$

Tkaczyk, E. R. (2017). Innovations and developments in dermatologic non-invasive optical imaging and potential clinical applications. Acta Derm. Venereol. 128, 5-13. doi: 10.2340/00015555-2717

Trivedi, P., Tray, N., Nguyen, T., Nigam, N., and Gallicano, G. I. (2010). Mesenchymal stem cell therapy for treatment of cardiovascular disease: helping people sooner or later. Stem Cells Dev. 19, 1109-1120. doi: 10.1089/scd.2009. 0465

Tseng, C.-L., Shih, I.-L., Stobinski, L., and Lin, F.-H. (2010). Gadolinium hexanedione nanoparticles for stem cell labeling and tracking via magnetic resonance imaging. Biomaterials 31, 5427-5435. doi: 10.1016/j.biomaterials. 2010.03.049

Turjeman, K., Bavli, Y., Kizelsztein, P., Schilt, Y., Allon, N., Katzir, T. B., et al. (2015). Nano-Drugs based on nano sterically stabilized liposomes for the treatment of inflammatory neurodegenerative diseases. PLoS One 10:e0130442. doi: 10.1371/journal.pone.0130442

Uccelli, A., Moretta, L., and Pistoia, V. J. (2008). Mesenchymal stem cells in health and disease. Nat. Rev. Immunol. 8, 726-736. doi: 10.1038/nri2395

Vagnozzi, R. J., Maillet, M., Sargent, M. A., Khalil, H., Johansen, A. K. Z., Schwanekamp, J. A., et al. (2020). An acute immune response underlies the benefit of cardiac stem cell therapy. Nature 577, 405-409. doi: 10.1038/s41586019-1802-2

Van Den Bos, E. J., Wagner, A., Mahrholdt, H., Thompson, R. B., Morimoto, Y., Sutton, B. S., et al. (2003). Improved efficacy of stem cell labeling for magnetic resonance imaging studies by the use of cationic liposomes. Cell Transplant. 12, 743-756. doi: 10.3727/000000003108747352

Walczak, P., and Bulte, J. W. (2007). The role of noninvasive cellular imaging in developing cell-based therapies for neurodegenerative disorders. Neurodegener. Dis. 4, 306-313. doi: 10.1159/000101887

Wang, C., Cheng, L., Xu, H., and Liu, Z. J. B. (2012a). Towards whole-body imaging at the single cell level using ultra-sensitive stem cell labeling with oligoarginine modified upconversion nanoparticles. Biomaterials 33, 4872-4881. doi: 10.1016/j.biomaterials.2012.03.047

Wang, C., Ma, X., Ye, S., Cheng, L., Yang, K., Guo, L., et al. (2012b). Protamine functionalized single-walled carbon nanotubes for stem cell labeling and in vivo raman/magnetic resonance/photoacoustic triple-modal imaging. Adv. Funct. Mater. 22, 2363-2375. doi: 10.1002/adfm.201200133

Wang, F., Banerjee, D., Liu, Y., Chen, X., and Liu, X. J. A. (2010). Upconversion nanoparticles in biological labeling, imaging, and therapy. Analyst 135, 18391854. doi: 10.1039/c0an00144a

Wang, Y., Xu, C., and Ow, H. J. T. (2013). Commercial nanoparticles for stem cell labeling and tracking. Theranostics 3:544. doi: 10.7150/thno.5634

Wu, C., Li, J., Pang, P., Liu, J., Zhu, K., Li, D., et al. (2014). Polymeric vectormediated gene transfection of MSCs for dual bioluminescent and MRI tracking in vivo. Biomaterials 35, 8249-8260. doi: 10.1016/j.biomaterials.2014.06.014
Wu, Y., Chen, L., Scott, P. G., and Tredget, E. E. (2007). Mesenchymal stem cells enhance wound healing through differentiation and angiogenesis. Stem Cells 25, 2648-2659. doi: 10.1634/stemcells.2007-0226

Xie, B., Gu, P., Wang, W., Dong, C., Zhang, L., Zhang, J., et al. (2016). Therapeutic effects of human umbilical cord mesenchymal stem cells transplantation on hypoxic ischemic encephalopathy. Am. J. Transl. Res. 8:3241.

Xie, Y., Liu, W., Zhang, B., Wang, B., Wang, L., Liu, S., et al. (2019). Systematic intracellular biocompatibility assessments of superparamagnetic iron oxide nanoparticles in human umbilical cord mesenchyme stem cells in testifying its reusability for inner cell tracking by MRI. J. Biomed. Nanotechnol. 15, 2179-2192. doi: 10.1166/jbn.2019.2845

Yao, M., Shi, X., Zuo, C., Ma, M., Zhang, L., Zhang, H., et al. (2020). Engineering of SPECT/Photoacoustic imaging/antioxidative stress triple-function nanoprobe for advanced mesenchymal stem cell therapy of cerebral ischemia. ACS Appl. Mater. Interfaces 12, 37885-37895. doi: 10.1021/acsami.0c10500

Ye, L., Chang, Y.-H., Xiong, Q., Zhang, P., Zhang, L., Somasundaram, P., et al. (2014). Cardiac repair in a porcine model of acute myocardial infarction with human induced pluripotent stem cell-derived cardiovascular cells. Cell Stem Cell 15, 750-761. doi: 10.1016/j.stem.2014.11.009

Ye, L., Haider, H. K., and Sim, E. K. (2006). Adult stem cells for cardiac repair: a choice between skeletal myoblasts and bone marrow stem cells. Exp. Biol. Med. 231, 8-19. doi: 10.1177/153537020623100102

Yi, D. K., Nanda, S. S., Kim, K., and Selvan, S. T. (2017). Recent progress in nanotechnology for stem cell differentiation, labeling, tracking and therapy. J. Mater. Chem. B 5, 9429-9451. doi: 10.1039/C7TB02532G

Yin, C., Wen, G., Liu, C., Yang, B., Lin, S., Huang, J., et al. (2018). Organic semiconducting polymer nanoparticles for photoacoustic labeling and tracking of stem cells in the second near-infrared window. ACS Nano 12, 12201-12211. doi: 10.1021/acsnano.8b05906

Young, H. E., and Black, A. C. (2004). Adult stem cells. Anat. Rec. A Discov. Mol. Cell Evol. Biol. 276, 75-102. doi: 10.1002/ar.a.10134

Yukawa, H., and Baba, Y. J. A. C. (2017). In vivo fluorescence imaging and the diagnosis of stem cells using quantum dots for regenerative medicine. Anal. Chem. 89, 2671-2681. doi: 10.1021/acs.analchem.6b 04763

Zampelas, A., and Magriplis, E. J. (2020). Dietary patterns and risk of cardiovascular diseases: a review of the evidence. Proc. Nutr. Soc. 79, 68-75. doi: 10.1017/S0029665119000946

Zhang, L., Gu, F., Chan, J., Wang, A., Langer, R., Farokhzad, O. J., et al. (2008). Nanoparticles in medicine: therapeutic applications and developments. Clin. Pharmacol. Ther. 83, 761-769. doi: 10.1038/sj.clpt.6100400

Zhang, S. J., and Wu, J. C. (2007). Comparison of imaging techniques for tracking cardiac stem cell therapy. J. Nucl. Med. 48, 1916-1919. doi: 10.2967/jnumed. 107.043299

Zhang, Z., Hancock, B., Leen, S., Ramaswamy, S., Sollott, S. J., Boheler, K. R., et al. (2010). Compatibility of superparamagnetic iron oxide nanoparticle labeling for $1 \mathrm{H}$ MRI cell tracking with 31P MRS for bioenergetic measurements. NMR Biomed. 23, 1166-1172. doi: 10.1002/nbm.1545

Zhao, L., Kutikov, A., Shen, J., Duan, C., Song, J., and Han, G. J. T. (2013). Stem cell labeling using polyethylenimine conjugated ( $\alpha-\mathrm{NaYbF} 4: \mathrm{Tm} 3+) / \mathrm{CaF} 2$ upconversion nanoparticles. Theranostics 3, 249-257. doi: 10.7150/thno.5432

Zheng, Y., Huang, J., Zhu, T., Li, R., Wang, Z., Ma, F., et al. (2017). Stem cell tracking technologies for neurological regenerative medicine purposes. Stem Cells Int. 2017:2934149. doi: 10.1155/2017/2934149

Zhu, D., Liu, F., Ma, L., Liu, D., and Wang, Z. J. (2013). Nanoparticle-based systems for T1-weighted magnetic resonance imaging contrast agents. Int. J. Mol. Sci. 14, 10591-10607. doi: 10.3390/ijms140510591

Conflict of Interest: The authors declare that the research was conducted in the absence of any commercial or financial relationships that could be construed as a potential conflict of interest.

Copyright (c) 2021 Huang, Du, He, Yan and Han. This is an open-access article distributed under the terms of the Creative Commons Attribution License (CC BY). The use, distribution or reproduction in other forums is permitted, provided the original author(s) and the copyright owner(s) are credited and that the original publication in this journal is cited, in accordance with accepted academic practice. No use, distribution or reproduction is permitted which does not comply with these terms. 